\title{
10. FRACTURE-CONTROLLED METAMORPHISM OF HESS DEEP GABBROS, SITE 894: CONSTRAINTS ON THE ROOTS OF MID-OCEAN-RIDGE HYDROTHERMAL SYSTEMS AT FAST-SPREADING CENTERS ${ }^{1}$
}

\author{
Craig E. Manning ${ }^{2}$ and C.J. MacLeod ${ }^{3}$
}

\begin{abstract}
Gabbros recovered at Site 894 during Leg 147 provide the first constraints on fracture formation and metamorphism in the root zones of hydrothermal systems at the fast-spreading East Pacific Rise. Metamorphism in the gabbros was related to fracture formation, fracture filling to form veins, and spatially associated fluid-rock reactions. The earliest veins are microscopic amphibole veins responsible for pervasive $(10 \%$ to $>50 \%)$ alteration of the gabbros to amphibolite-facies mineral assemblages which record metamorphic temperatures of $600^{\circ}-750^{\circ} \mathrm{C}$. Metamorphism associated with these veins locally occurred to lower temperatures of the greenschist-amphibolite transition. Rare macroscopic amphibole veins everywhere crosscut the microscopic veins. They are filled by mineral assemblages consistent with formation in the amphibolite facies to the greenschistamphibolite transition $\left(450^{\circ}-600^{\circ} \mathrm{C}\right)$. Crosscutting the amphibole veins are chlorite-calc-silicate veins and chlorite-smectite veins. Together, these vein types define prominent, regular sets which are abundant at Site 894. Chlorite-calc-silicate vein assemblage imply formation in the greenschist facies $\left(250^{\circ}-450^{\circ} \mathrm{C}\right)$, whereas the chlorite-smectite vein assemblage probably reflects lower, sub-greenschist facies conditions $\left(<300^{\circ} \mathrm{C}\right)$. Latest zeolite-calcite veins are rare, display no alteration halos, and formed at very low temperatures.

Reorientation of core pieces to present geographical coordinates demonstrates that macroscopic amphibole veins show no preferred orientation, whereas chlorite-bearing vein types display strong preferred east-west strikes with moderate to steep dips. Combination of these observations with petrologic and theoretical constraints on the temperatures and timing of mineral formation suggests formation of amphibolite-facies mineral assemblages within $60,000 \mathrm{yr}$ and several kilometers of axial emplacement at the East Pacific Rise. The east-west strikes of later chlorite-bearing veins suggest formation when the westwardpropagating Cocos-Nazca Spreading Center rifted the newly formed EPR crust to form Hess Deep. This may have taken place up to tens of kilometers and several hundred thousand years after gabbro emplacement. The inferred temperatures of up to $750^{\circ} \mathrm{C}$ for the onset of brittle failure and fluid-rock interaction in the gabbroic portion of fast-spread oceanic crust are higher than has previously been recognized. In addition, variable metamorphic temperatures and alteration extents imply that microfracturing did not proceed along a homogeneous isothermal cracking front; rather it developed heterogeneously in both space and time. However, high temperatures and a dependence of metamorphic mineral composition on grain-scale bulk compositional variation argue for low time-integrated fluid fluxes and rapid reaction rates.
\end{abstract}

\section{INTRODUCTION}

Oceanic hydrothermal systems are driven by thermal energy liberated from cooling magma. In conceptual models of these systems, sea water is drawn downward toward a cooling axial magma body and heated near the interface between solidified intrusive rocks and magma. The fluids then advect thermal energy out of the crust during rapid, buoyant rise and discharge at the ocean floor (e.g., Lowell, 1975; Lister, 1983; Strens and Cann, 1982, 1986; Cann et al., 1985; Lowell and Burnell, 1991; Lowell and Germanovich, 1994). The hydrochemical evolution of these systems depends strongly on the origin, timing, and spatial distribution of permeability in and near the magmatic heat source; that is, in their high-level gabbroic root zones.

Petrologic constraints on pore-network evolution and fluid-rock interaction in the root zones of oceanic hydrothermal systems come from metamorphosed oceanic gabbros. Studies of these rocks have

'Mével, C., Gillis, K.M., Allan, J.F., and Meyer, P.S. (Eds.), 1996. Proc. ODP, Sci. Results, 147: College Station, TX (Ocean Drilling Program).

${ }^{2}$ Department of Earth and Space Sciences, University of California, Los Angeles, CA 90024-1567, U.S.A

${ }^{3}$ Department of Earth Sciences, University of Wales College of Cardiff, P.O. Box 914, Cardiff CF1 3YE, United Kingdom. Formerly at: Institute of Oceanographic Sciences, Brook Road, Wormley, Surrey GU8 5UB, United Kingdom; and Borehole Research, Department of Geology, University of Leicester, Leicester LEI 7RH, United Kingdom.macleod@cardiff.ac.uk focused principally on slow-spreading environments where exposures of lower crustal lithologies are common (e.g., Bonatti et al., 1975; Helmstaedt and Allen, 1977; Mével et al., 1978; Ito and Anderson, 1983; Prichard and Cann, 1982; Honnorez et al., 1984; Mével, 1987, 1988; Cannat et al., 1991; Dick et al., 1991; Stakes et al., 1991; Gillis et al., 1993b; Kelley et al., 1993). These investigations show that in slow-spreading environments, early high-temperature plastic deformation in shear zones provided the initial permeability which allowed penetration of sea water into the gabbros at near-solidus to amphibolite-facies conditions $\left(\sim 750^{\circ}\right.$ to $\left.550^{\circ} \mathrm{C}\right)$. Later brittle deformation, expressed by features such as tensile fractures, sheared cataclastic zones, and breccias, formed at lower temperatures ranging from the amphibolite to greenschist or sub-greenschist facies $(\sim 600$ to $<300^{\circ} \mathrm{C}$ ). High-temperature ductile shear zones develop at slowspreading ridges such as the Mid-Atlantic Ridge and the southwest Indian Ridge because of amagmatic extension caused by insufficient magma supply, but are thought to be absent at fast-spreading centers such as the East Pacific Rise, where magma supply is more continuous (Harper, 1985; Karson et al., 1987; Karson, 1990; Cannat and Mével, 1991; Cannat et al., 1991; Mével and Cannat, 1991).

The inferred absence of early high-temperature plastic deformation in gabbros in fast-spreading environments led Mével and Cannat (1991) to hypothesize that the inception of fluid-rock interaction would take place at lower temperatures $\left(<500^{\circ} \mathrm{C}\right)$ than those observed in slow-spreading environments. Although spreading rate may not be the only control on the physical and chemical behavior of oceanic 
crust (e.g., Rona, 1988; Agar, 1994), Mével and Cannat's model serves as a useful framework within which to compare the history of metamorphism and fluid flow in gabbros from different settings, but it is inherently limited by insufficient sampling of intrusive lithologies from ridges with fast-spreading rates. Rare metagabbros sampled from the fast-spreading environments such as the East Pacific Rise (EPR) are from areas complicated by changes in spreading rate (Mathematician Ridge; Batiza and Vanko, 1985; Stakes and Vanko, 1986) or from transform fault zones where mid-ocean ridge processes may be obscured by transform-related deformation (Bideau et al., 1991). As a result, comparisons of hydrothermal processes in the plutonic portions of fast- and slow-spreading centers have relied primarily on the metamorphic record in the Oman ophiolite (Gregory and Taylor, 1981; Stakes et al., 1983; Nehlig and Juteau, 1988; Stakes and Taylor, 1992; Nehlig, 1993, 1994), which is generally thought to represent fast-spread oceanic crust (Nicolas, 1989). However, the ophiolite's complex igneous and emplacement history (e.g., Lippard et al., 1986) has had an unknown effect on metamorphism and hydrothermal fluid flow, highlighting the need for in-situ samples of plutonic rocks from fast-spreading ridges.

Here we describe the mineralogic, temporal, and spatial characteristics of vein systems in massive (non-layered) gabbros formed at $\sim 1 \mathrm{Ma}$ at the fast-spreading East Pacific Rise and drilled in Ocean Drilling Program (ODP) Hole 894G of Leg 147 at Hess Deep. We have made systematic mineralogic observations and, where possible, orientation measurements of all hydrothermal veins and associated metamorphism throughout the cores of Hole $894 \mathrm{G}$. We use this information to establish a temperature-time history for the subsolidus cooling and hydrothermal alteration of the gabbros in the context of the tectonic evolution of Hess Deep. Our results constrain, for the first time, the thermal, hydrologic, and metamorphic evolution of the plutonic section of fast-spread oceanic crust.

\section{Geologic Setting}

Hess Deep (Fig, 1) is a $>5$-km-deep rift valley in $\sim 1$ Ma oceanic crust generated at the East Pacific Rise (Hey et al., 1972; Johnson et al., 1976; Kashintsev et al., 1982; Searle and Francheteau, 1986; Lonsdale, 1988; Francheteau et al., 1990). Located at the western terminus of the Cocos-Nazca Spreading Center, the valley is $\sim 50$ to 100 $\mathrm{km}$ east of the present East Pacific Rise. Hess Deep and Dietz Deep to the south form two of the three boundaries of the Galapagos microplate at the triple junction defined by the East Pacific Rise and the Cocos-Nazca Spreading Center (Fig. 1; Lonsdale, 1988). Lithologies exposed in the steep scarps of Hess Deep include serpentinized ultramafic rocks, gabbroic rocks, sheeted dikes, and pillow lavas (Kashintsev et al., 1982; Francheteau et al., 1990; Girardeau and Francheteau, 1993; Hekinian et al., 1993). The valley thus contains a unique composite section of EPR crust generated rapidly at a half spreading rate of $65 \mathrm{~mm} / \mathrm{yr}$ (Lonsdale, 1988; Francheteau et al., 1990).

Holes $894 \mathrm{~F}$ and $894 \mathrm{G}$ penetrated metamorphosed unlayered varitextured gabbroic rocks exposed on the intrarift ridge, a horst block within Hess Deep. Hole $894 \mathrm{~F}$ is $25.7 \mathrm{~m}$ deep in a section of cataclastically deformed gabbros. Hole $894 \mathrm{G}$ was sited about $5 \mathrm{~m}$ northnortheast of Hole $894 \mathrm{~F}$; the first $18.6 \mathrm{~m}$ were drilled but not cored and the borehole penetrated $154.5 \mathrm{~m}$ with $35.4 \%$ recovery overall (Shipboard Scientific Party, 1993). Although the two holes thus represent a composite gabbro section, most of our observations are based on studies of Hole $894 \mathrm{G}$ from $>20$ m below seafloor (mbsf), away from the cataclastic deformation found at the highest levels of the site (Früh-Green, Plas, and Dell'Angelo, this volume). Gabbroic lithologies included gabbros, olivine gabbros, gabbronorites, and olivine gabbronorites with variable and low oxide and sulfide contents and poikilitic to equigranular textures, but for simplicity we refer to these rocks as gabbros. No evidence for modal layering was observed, but a steep magmatic foliation defined by alignment of tabular plagio-

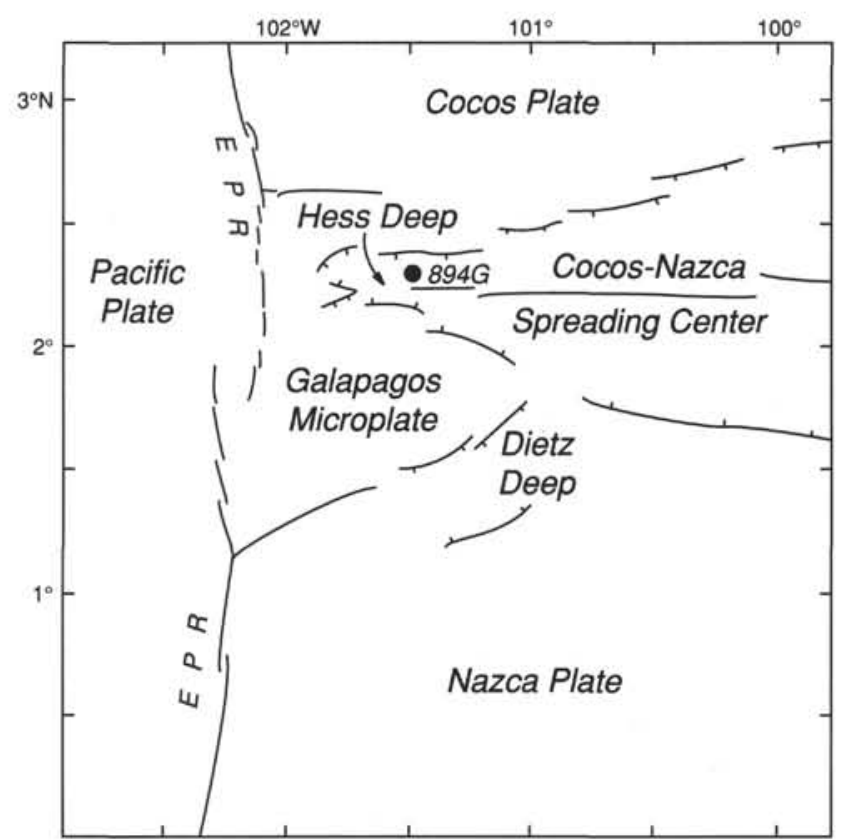

Figure 1. Map showing location of Site 894 (after Lonsdale, 1988). Lines with tics demarcate rift valleys. EPR $=$ East Pacific Rise.

clase crystals is locally developed throughout the core (Shipboard Scientific Party, 1993; MacLeod, Boudier, et al., this volume). When restored to geographic coordinates, this foliation parallels the EPR axis (MacLeod, Boudier, et al., this volume), supporting an origin of the cored gabbros at the East Pacific Rise.

Of central importance in studies of fracture-controlled metamorphism in magma-hydrothermal systems is knowledge of the geometry and location of the magma chamber relative to the rock suite of interest. Recent investigations demonstrate that magma chambers of the East Pacific Rise are small sill-like bodies (Detrick et al., 1987, 1993; Burnett et al., 1989; Kent et al., 1990; Toomey et al., 1990; Vera et al., 1990; Wilcock et al., 1992). As summarized by Sinton and Detrick (1992), the tops of EPR magma chambers are 1.2-2.4 km below seafloor, with widths of 1-2 km and thicknesses of a few hundred meters. Along the North Wall of Hess Deep, gabbros petrographically and compositionally equivalent to those of Hole $894 \mathrm{G}$ are immediately overlain by oxide-bearing and oxide-rich ferrogabbro cumulates inferred to represent the crystallized axial melt lens (Natland and Dick, this volume). In addition, submersible observations suggest that more primitive cumulate gabbros and ultramafic rocks are exposed downslope (downsection) from Site 894 (Francheteau et al., 1990). Taken together, these observations suggest that if the geometry of the magma chamber during generation of the oceanic crust now exposed at Site 894 was similar to that of present-day EPR magma chambers, then Hole $894 \mathrm{G}$ gabbros most likely represent a stratigraphic position immediately beneath an axial magma lens (Natland and Dick, this volume), probably corresponding to a crystallization depth of $2-3 \mathrm{~km}$ below seafloor.

\section{METHODS}

We investigated the fracture-controlled metamorphism at Site 894 by combining petrographic and structural studies of mineral-filled fractures (veins) with borehole-wall imaging data and electron microprobe analyses. In Hole 894G, 1040 macroscopic veins were identified during shipboard core logging and subsequent shore-based redescription. For each vein, its location, width, length, crosscutting 
Table 1. Summary of crosscutting relations between vein types.

\begin{tabular}{lccccc}
\hline Early veins: & $\begin{array}{c}\text { Microscopic } \\
\text { amphibole } \\
\text { veins }\end{array}$ & $\begin{array}{c}\text { Macroscopic } \\
\text { amphibole } \\
\text { veins }\end{array}$ & $\begin{array}{c}\text { Chlorite- } \\
\text { calcite-silicate } \\
\text { veins }\end{array}$ & $\begin{array}{c}\text { Chlorite- } \\
\text { smectite } \\
\text { veins }\end{array}$ & $\begin{array}{c}\text { Zeolite- } \\
\text { calcite } \\
\text { veins }\end{array}$ \\
\hline $\begin{array}{l}\text { Late veins } \\
\text { Microscopic amphibole veins }\end{array}$ & NA & 0 & 0 & 0 & 0 \\
Macroscopic amphibole veins & 4 & 0 & 0 & 0 & 0 \\
Chlorite-calcite-silicate veins & 16 & 2 & 2 & 3 & 0 \\
Chlorite-smectite veins & 7 & 6 & 8 & 15 & 0 \\
Zeolite-calcite veins & NA & 0 & 4 & 2 & 0 \\
\hline
\end{tabular}

Notes: For a given crosscutting relation, an early vein type (columns) crosscuts a later vein type (rows). Entries reflect number of observations of each possible crosscutting relation. For any pair of vein types, observations only below the diagonal indicate consistent age relations, whereas observations both above and below diagonal signify mutually crosscutting relations. Observations on the diagonal refer to crosscutting relations for veins of the same type. NA = not analyzed.

relations, color, mineral fill, and associated wall-rock alteration were recorded. These data, along with a description of the methods of data collection, are given by Manning et al. (this volume). Optical petrography revealed the existence of an additional microscopic vein type. Similar data were collected for this vein type to the extent possible based on microscopic observation of representative thin sections.

Mineral compositions were determined using a Cameca Camebax electron microprobe at UCLA. Operating conditions were $15-\mathrm{kV}$ accelerating potential, 15-nA beam current, and 20-s counting times. A focused $(\sim 1 \mathrm{~mm})$ beam was used for all minerals except plagioclase, for which the beam was defocused to $\sim 5 \mathrm{~mm}$. A ZAF correction algorithm was used with well-characterized natural and synthetic standards. $\mathrm{Fe}^{3+}$ was calculated by charge balance in amphiboles and clinopyroxenes following Papike et al. (1974) and Robinson et al. (1982).

Of the 1040 macroscopic veins present in the recovered cores from Hole 894G, 601 were in core pieces that could be oriented relative to the fiducial axis of the borehole and 303 were in pieces for which the stable magnetic remanence direction has also been determined (MacLeod, Célérier, et al., this volume). Orienting core pieces relative to this stable remanence direction can provide a common reference frame for comparing veins and other features in the core, assuming that all samples acquired their magnetizations under the same field conditions. This assumption is reasonable for the gabbroic rocks drilled at Site 894, which are likely to have cooled sufficiently slowly for secular variations of the Earth's magnetic field to be averaged out. Knowledge of the core magnetization direction is not, however, sufficient in itself to determine the true orientations of structures: the horizontal component of the stable magnetic remanence direction can only be equated with present-day north or south if it can be demonstrated that there has been no tectonic rotation of the sample after the magnetization was acquired. At Sites 894 and 895, magnetic inclinations consistently dip at approximately $+40^{\circ}$ (down toward the declination direction), contrasting markedly with the expected inclination of the axial dipole field of $+4.6^{\circ}$ for this latitude, and leading us to suspect that some tectonic rotation of the Hess Deep intra-rift ridge has occurred (Shipboard Scientific Party, 1993; MacLeod, Célérier, et al., this volume; MacLeod, Manning, et al., this volume). Thus the stable magnetic remanence direction does not necessarily point toward north or south.

The only reliable indication of fracture orientation in geographical coordinates comes from downhole measurements of the borehole wall. On Leg 147, Formation MicroScanner (FMS) microresistivity images were obtained for a $35-\mathrm{m}$ interval ( $45-80 \mathrm{mbsf}$ ) of the wall of Hole 894G (Célérier et al., this volume; MacLeod, Manning, et al., this volume). These images are oriented reliably in the geographical reference frame (Ekstrom et al., 1987). By comparing the distributions of veins in the core restored partially relative to the magnetization direction with the distributions of fractures on the logs, the FMS images allow the vein measurements to be reoriented fully to geographical coordinates. The principles and methodology of this tech- nique are discussed in detail by MacLeod et al. (1992, 1994), and its specific application to the present data set has also been made by MacLeod, Célérier, et al. (this volume) and Célérier et al. (this volume).

\section{FRACTURE-CONTROLLED METAMORPHISM AT SITE 894}

All gabbroic rocks from Site 894 are metamorphosed, and metamorphism does not depend on lithology (Shipboard Scientific Party, 1993). The extent of replacement of magmatic minerals by secondary minerals is at least $10 \%$ in Hole $894 \mathrm{G}$, and ranges to $>50 \%$ (Shipboard Scientific Party, 1993). Metamorphism is related to the penetration of the gabbros by aqueous solutions through fractures at a range of scales. Crosscutting relations and metamorphic grades of mineral-fluid interaction thus provide a record of the spatial and temporal evolution of hydrothermal circulation during the cooling history of the gabbros at Site 894. We grouped veins on the basis of their two scales of occurrence-microscopic and macroscopic-because veins at these two scales are temporally, mineralogically, and texturally distinct. A second-order subdivision of macroscopic veins based on mineral fill yielded three types: macroscopic amphibole, chlorite, and zeolite-calcite veins. Chlorite veins were further subdivided into chlorite-calc-silicate veins and chlorite-smectite veins. Below, we describe textures and mineral compositions of these veins types in order of oldest to youngest as established by crosscutting relations (Table 1). With the possible exception of the cataclastically deformed zones not discussed in the present paper (see Früh-Green, Plas, and Dell'Angelo, this volume), no shear displacements are displayed by any of the vein types we examined. This suggests that the veins resulted from tensile brittle failure.

\section{Microscopic Veins and Associated Alteration}

The earliest veins are filled by green, blue-green, and olive-green calcic amphibole (Table 1) and can be observed only in thin section. They are therefore referred to as microscopic amphibole veins. Microscopic amphibole veins occur along grain boundaries (Pl. 1, Fig. 1) and also form subordinate fractures that crosscut magmatic minerals (Pl. 1, Fig. 2). They are rarely continuous as discrete features for more than five adjacent mineral grains; however, most intersect at least one other microscopic amphibole vein within the planes of thin sections, suggesting that these features record a microscopic fracture network with ample connectivity. The veins occur pervasively throughout the core, as they are present in every thin section examined in this study. The extent of associated wall-rock alteration varies widely in individual thin sections and throughout the core, but constitutes the most voluminous alteration at Site 894, accounting for at least $10 \%$ replacement of magmatic phases by secondary minerals in every sample examined. 
Maximum widths of veins crosscutting plagioclase grains are up to $40 \mu \mathrm{m}$. Figure $2 \mathrm{~A}$ shows the measured width distribution for 51 microscopic amphibole veins from Sample 147-894G-12R-3, Piece $2,56-59 \mathrm{~cm}$. The mean width is $17 \mu \mathrm{m}$, and few of the veins in this sample exceed $20 \mu \mathrm{m}$ in width.

Inspection of mutual junctions between different mineral pairs suggests that the abundance of microscopic amphibole veins varies with the identities of adjoining minerals. This was assessed by conducting two reconnaissance traverses of thin sections of oriented samples in which each grain boundary encountered was inspected for the presence or absence of calcic amphibole (Table 2). Traverses were at right angles to the axis of the borehole. Amphibole textures range from minute, discrete prismatic to acicular crystals decorating grain boundaries to complete infilling of the grain boundary regions by polycrystalline aggregates of hornblende. Of 188 grain boundaries encountered in these traverses, 153 contained amphibole. This suggests that, despite the low modal abundance of secondary minerals in these samples, more than $80 \%$ of the grain boundaries hosted fluid flow that resulted in the formation of secondary minerals. In addition, about two thirds of plagioclase-plagioclase contacts contain amphibole, independent of the total modal abundance of secondary minerals (Table 2). By contrast, the number of clinopyroxene-plagioclase junctions now containing amphibole increases from $44 \%$ to $61 \%$ with an increase in modal volume of secondary minerals from $10 \%$ to $20 \%$. This implies that increasing access of fluids to plagioclaseclinopyroxene grain junctions increases the overall extent of mineralogic alteration in the core.

The microscopic amphibole veins are filled by calcic aluminous amphibole. Representative compositions are given in Table 3. Selected compositional characteristics of the amphiboles filling the early microcracks are given in Figures 3A through 3I. Figures $3 \mathrm{~A}, 3 \mathrm{D}$, and $3 \mathrm{G}$ show that, assuming $\mathrm{Fe}_{2} \mathrm{O}_{3}$ concentration is the mid-point between minimum and maximum allowable by charge balance, amphibole compositions are dominantly magnesio-hornblende in the nomenclature of Leake (1978). A total of 83 analyses give a mean mole fraction of $\mathrm{Mg}\left(X_{\mathrm{Mg}}=n_{\mathrm{Mg}} /\left(n_{\mathrm{Mg}}+n_{\mathrm{Fe}^{2+}}\right)\right.$, where $n$ is number of atoms per 23 anhydrous oxygens) of 0.66 and mean tetrahedral $\mathrm{Al}$ ( ${ }^{\mathrm{IV}} \mathrm{Al}$ ) of 0.79 atoms assuming 8 tetrahedral atoms per 23 anhydrous oxygens. It can also be seen that $X_{\mathrm{Mg}}$ decreases with increasing ${ }^{\mathrm{IV}} \mathrm{Al}$. A-site occupancy ranges from 0 to 0.6 (Fig. 3B, E, H).

Figures $3 \mathrm{D}$ through $3 \mathrm{~F}$ illustrate that the composition of calcic amphibole in grain boundaries varies as a function of adjoining minerals. Amphiboles found at plagioclase-plagioclase grain boundaries have higher ${ }^{\mathrm{IV}} \mathrm{Al}$ and higher $\mathrm{A}$-site occupancy than those found at clinopyroxene-clinopyroxene junctions, whereas those at clinopyroxene-plagioclase junctions are intermediate in composition. Together, all analyses define a continuous range in composition from actinolite to magnesio-hornblende. Note that Ti content increases with increasing ${ }^{\mathrm{IV}} \mathrm{Al}$ for amphiboles coexisting with clinopyroxene, but is low $(<0.05)$ for aluminous amphiboles at plagioclase-plagioclase grain boundaries.

Medium- to coarse-grained to gabbronorites locally display more extensive alteration (Fig. 4). Amphiboles found in these rocks range from, in order of oldest to youngest based on overgrowth textures, subhedral brown magnesio-hornblende through blue-green hornblende to actinolite. Alteration patches are locally vuggy. The subhedral to euhedral textures and preservation of open space suggest that early amphibole formation in these zones may have occurred during the latest stages of crystallization, possibly from magmatic fluids (Gillis, this volume; Kelley and Malpas, this volume). Where clinopyroxene is altered in these rocks, two distinct amphibole types are found (Fig. 3G-I). Paragenetically, early amphiboles are Ti-rich magnesio-hornblendes, whereas later amphibole overgrowths are Tipoor actinolites.

Wall-rock alteration associated with microscopic amphibole veins differs depending on the mineral hosting the vein. Plagioclase
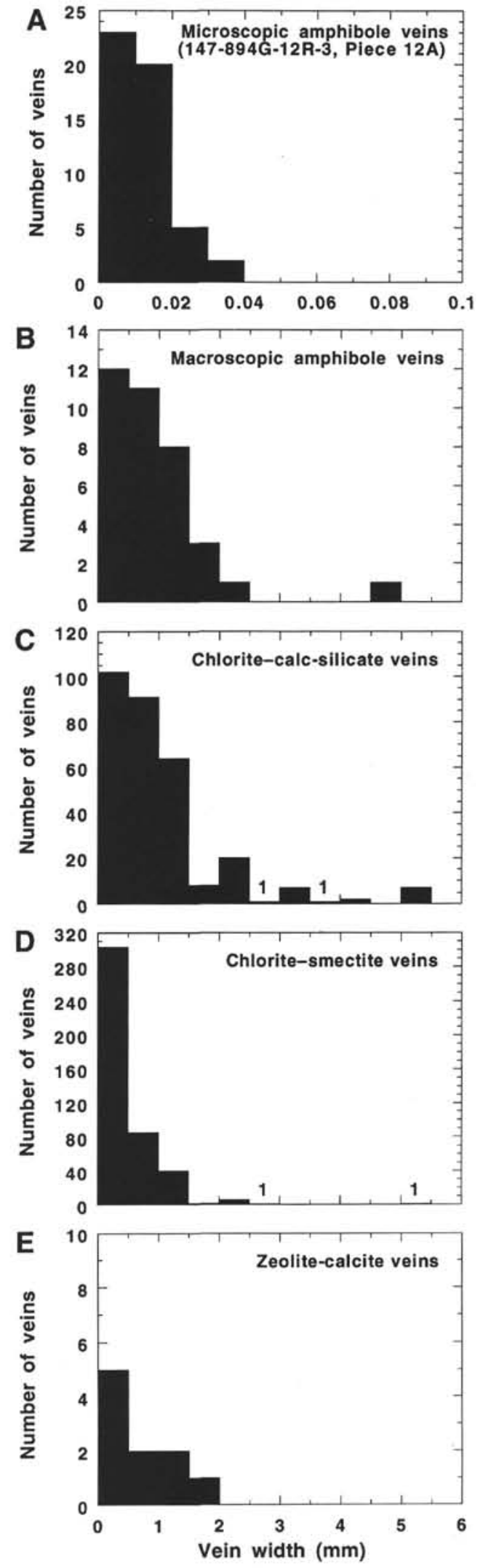

Figure 2. A-E. Histograms of vein widths. 
Table 2. Distribution of microscopic amphibole veins in grain-boundary regions.

\begin{tabular}{llcccccr}
\hline \multicolumn{1}{c}{ Sample } & & $\begin{array}{c}\text { Plag-plag } \\
\text { junctions }\end{array}$ & $\begin{array}{l}\text { Cpx-plag } \\
\text { junctions }\end{array}$ & $\begin{array}{l}\text { Cpx-cpx } \\
\text { junctions }\end{array}$ & $\begin{array}{l}\text { Opx-plag } \\
\text { junctions }\end{array}$ & $\begin{array}{l}\text { Opx-cpx } \\
\text { junctions }\end{array}$ & Totals \\
\hline 147-894G-17R-2 & Vein absent: & 10 & 24 & 4 & 3 & 2 & 43 \\
(Piece 5, 44 47 cm) & Vein present: & 19 & 19 & 1 & 2 & 1 & 42 \\
$11 \%$ secondary minerals & Totals: & 29 & 43 & 5 & 5 & 3 & 85 \\
$147-894 G-12 R-3$ & Vein absent: & 8 & 22 & 5 & 0 & 0 & 35 \\
(Piece 2, 56-59 cm) & Vein present: & 19 & 34 & 10 & 4 & 1 & 68 \\
22\% secondary minerals & Totals: & 27 & 56 & 15 & 4 & 1 & 103 \\
\hline
\end{tabular}

Notes: Grain-boundary vein abundances determined by counting number of grain boundaries occupied by calcic amphibole along representative 5 -mm traverses. Plag = plagioclase, $\mathrm{cpx}=$ clinopyroxene, and opx $=$ orthopyroxene.

Table 3. Representative compositions of amphiboles in microscopic amphibole veins and associated alteration, Hole 894G.

\begin{tabular}{|c|c|c|c|c|c|c|c|c|c|}
\hline & \multicolumn{4}{|c|}{ Microscopic vein fill by grain-boundary type } & \multicolumn{5}{|c|}{ Wall-rock alteration } \\
\hline & Cpx-cpx & Plag-plag & Plag-plag & Cpx-plag & After opx & After cpx & After cpx & After plag & After oxide \\
\hline Core, section: & $13 R-1-11 B$ & 13R-1 & 13R-1 & 17R-2 & $13 R-1$ & 18R-2 & $9 \mathrm{R}-3$ & $17 \mathrm{R}-2$ & $17 \mathrm{R}-1$ \\
\hline Analysis no.: & 23 & 34 & 46 & 16 & 36 & 44 & 44 & 41 & 54 \\
\hline Name: & Act-hbd & Act-hbd & Fe parg-hbd & Act-hbd & Cumm & Mg-hbd & Mg-hbd & Mg-hbd & Fe-hbd \\
\hline $\mathrm{SiO}_{2}$ & 51.46 & 49.53 & 43.07 & 50.78 & 53.81 & 48.98 & 46.22 & 48.02 & 45.34 \\
\hline $\mathrm{Al}_{2} \mathrm{O}_{3}$ & 4.33 & 5.61 & 12.26 & 5.21 & 2.58 & 6.89 & 7.36 & 8.40 & 7.77 \\
\hline $\mathrm{FeO}$ & 13.36 & 14.19 & 16.55 & 12.09 & 15.79 & 12.79 & 16.96 & 12.42 & 22.49 \\
\hline $\mathrm{MnO}$ & 0.32 & 0.26 & 0.24 & 0.29 & 0.39 & 0.12 & 0.26 & 0.19 & 0.23 \\
\hline $\mathrm{Cr}_{2} \mathrm{O}_{3}$ & 0.08 & 0.06 & 0.01 & 0.00 & 0.03 & 0.23 & 0.00 & 0.00 & 0.21 \\
\hline $\mathrm{K}_{2} \mathrm{O}$ & 0.07 & 0.07 & 0.20 & 0.06 & 0.05 & 0.09 & 0.21 & 0.11 & 0.28 \\
\hline $\mathrm{CaO}$ & 11.80 & 11.30 & 11.36 & 11.80 & 7.51 & 11.95 & 11.42 & 11.74 & 11.28 \\
\hline $\mathrm{TiO}_{2}$ & 0.70 & 0.27 & 0.11 & 0.48 & 0.25 & 1.14 & 1.89 & 0.21 & 0.50 \\
\hline \multicolumn{10}{|c|}{ Atoms per 23 anhydrous oxygens } \\
\hline $\mathrm{vi}_{\mathrm{Al}}$ & 0.208 & 0.254 & 0.603 & 0.176 & 0.139 & 0.268 & 0.167 & 0.315 & 0.298 \\
\hline $\mathrm{Fe}^{2+}$ & 1.448 & 1.396 & 1.621 & 1.089 & 1.795 & 1.409 & 1.877 & 0.985 & 2.519 \\
\hline $\mathrm{Fe}^{3+}$ & 0.174 & 0.349 & 0.449 & 0.364 & 0.096 & 0.140 & 0.234 & 0.506 & 0.345 \\
\hline $\mathrm{Mg}$ & 3.129 & 3.030 & 2.367 & 3.370 & 3.706 & 3.058 & 2.545 & 3.239 & 1.800 \\
\hline $\mathrm{Mn}$ & 0.039 & 0.032 & 0.030 & 0.035 & 0.047 & 0.015 & 0.032 & 0.023 & 0.030 \\
\hline $\mathrm{Ti}$ & 0.076 & 0.030 & 0.012 & 0.052 & 0.027 & 0.124 & 0.212 & 0.023 & 0.058 \\
\hline $\mathrm{Ca}$ & 1.835 & 1.780 & 1.820 & 1.816 & 1.152 & 1.854 & 1.820 & 1.806 & 1.840 \\
\hline $\mathrm{Na}$ & 0.138 & 0.277 & 0.635 & 0.248 & 0.067 & 0.421 & 0.487 & 0.429 & 0.431 \\
\hline $\mathrm{K}$ & 0.013 & 0.013 & 0.038 & 0.011 & 0.009 & 0.017 & 0.039 & 0.020 & 0.055 \\
\hline $\mathrm{Cr}$ & 0.009 & 0.007 & 0.001 & 0.000 & 0.003 & 0.026 & 0.000 & 0.000 & 0.025 \\
\hline Total & 15.070 & 15.169 & 15.577 & 15.160 & 15.040 & 15.332 & 15.413 & 15.345 & 15.400 \\
\hline
\end{tabular}

Notes: $\mathrm{Fe}^{3+}$ is midpoint between minimum and maximum calculated by charge balance. $\mathrm{Cpx}=$ clinopyroxene, plag $=$ plagioclase, opx $=$ orthopyroxene, act-hbd $=$ actinolitic hornblende; Fe parg-hbd = ferroan pargasitic hornblende; cumm = cummingtonite, $\mathrm{Mg}$-hbd = magnesio-hornblende, and Fe-hbd = ferro-hornblende.

grains at the margins of microscopic amphibole veins are optically identical to unaffected magmatic plagioclase (PI. 1, Figs. 1, 2), and major and minor element compositions of grains at vein margins are the same as magmatic compositions (Table 4; Fig. 5). However, locally in coarse-grained gabbros where paragenetic relations imply a longer alteration history, magmatic plagioclase is altered to more sodic secondary plagioclase $\left(X_{\mathrm{An}}=0.15-0.42\right.$; Fig. 5 ) where adjoining grain-boundary amphibole is paragenetically late actinolite and actinolitic hornblende (e.g., Fig. 3G-I).

In contrast to plagioclase, magmatic clinopyroxene was more strongly altered during the microscopic amphibole vein event. Where microscopic amphibole veins crosscut clinopyroxene, alteration of this phase may extend more than ten vein widths into the gabbros. Local patches of altered clinopyroxene not associated with obvious microscopic amphibole veins probably result from microscopic veins out of the plane of the thin section. Clinopyroxene is primarily altered to calcic amphibole ranging from actinolite to magnesio-hornblende (Fig. 3D-F). Typical throughout the core are rims and discrete granular grains of clinopyroxene coexisting with magnetite at the interface between calcic amphibole and magmatic clinopyroxene. Where they are well developed, they can be seen with the aid of a hand lens on cut core surfaces as minute white patches and granules. These clinopyroxenes are optically translucent and unexsolved, in contrast to colorless-to-pink, exsolved magmatic grains which appear "dusty" in thin section because of numerous submicron-sized oxide inclusions (PI. 1, Figs. 3, 4). The translucent grains commonly share the same optical orientation as exsolved magmatic clinopyroxene. These textural characteristics are identical to those identified by Manning and Bird (1986) as being diagnostic of secondary clinopyroxene formed during hydrothermal alteration of magmatic clinopyroxene.

The compositions of secondary clinopyroxene are distinct from those of magmatic clinopyroxene (Fig. 6; Table 5). Figure 6 shows that the outermost portions ("rims") of texturally secondary clinopyroxenes have fewer $\mathrm{Ti}$ atoms per 6 oxygen formula unit (apfu) than magmatic clinopyroxenes ( $<0.010 \mathrm{vs.}>0.018$, respectively). Secondary patches adjacent to texturally magmatic clinopyroxene and centers of secondary grains ("cores") have Ti contents spanning the entire range of observed values. Similarly, with one exception, there are $<0.040 \mathrm{Al}$ apfu in secondary clinopyroxene rims, as opposed to $>0.070$ apfu in magmatic grains (Fig. 6D). Al contents in cores of secondary grains are again intermediate in composition, ranging from 0.010 to 0.100 apfu. Si occupancy in tetrahedral sites in secondary 

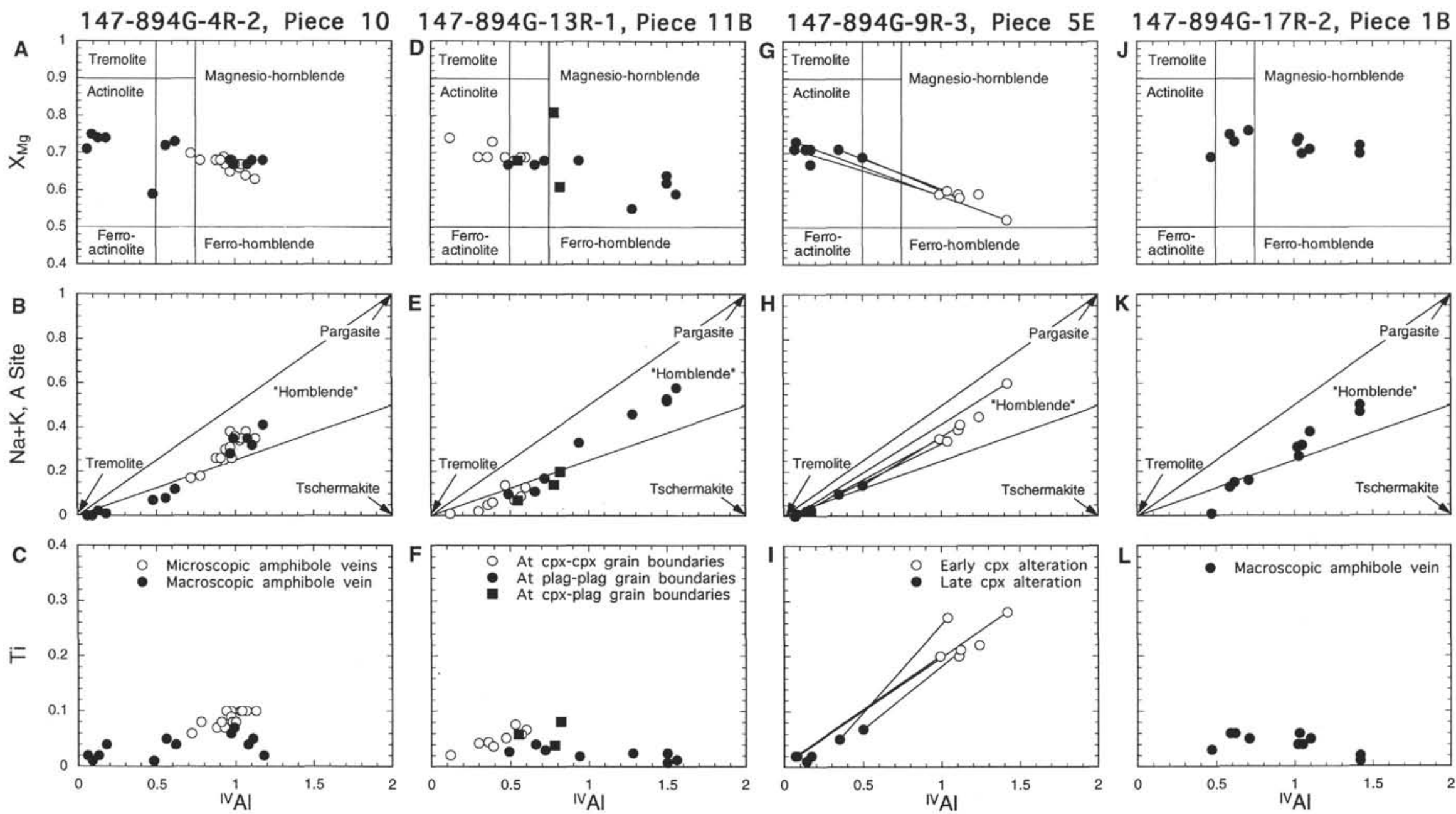

Figure 3. A-L. Compositions of calcic amphiboles in Hole $894 \mathrm{G}$. Fe ${ }^{3+}$ is the midpoint between the minimum and maximum allowable to balance charge (see text). Lines linking symbols show coexisting phases. Nomenclature after Leake (1978). $c p x=$ clinopyroxene, and plag $=$ plagioclase. 


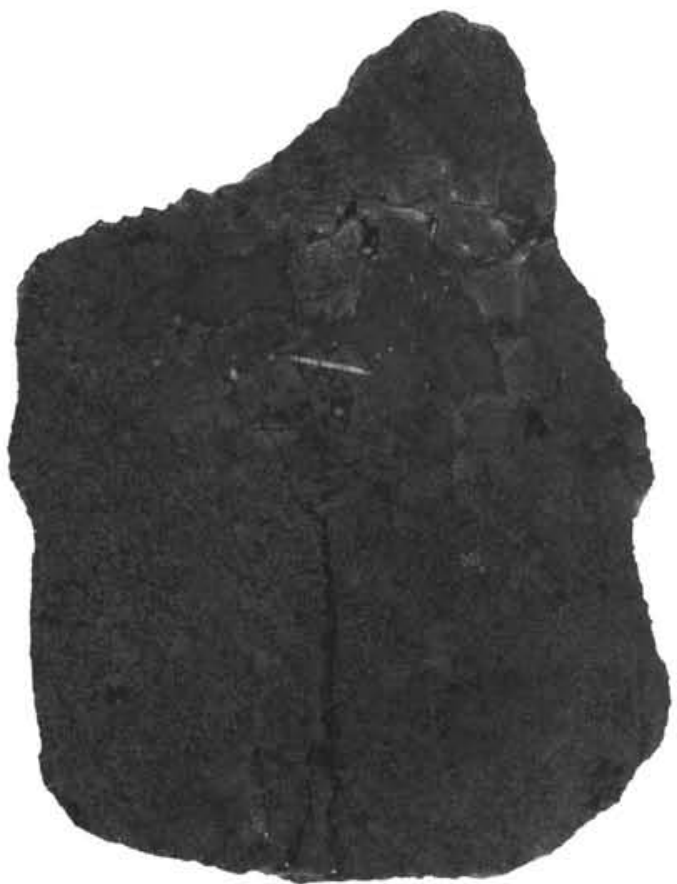

Figure 4. Extensive alteration related to microscopic amphibole veins in coarse-grained apatite-bearing gabbronorite Sample 147-894G-17R-1-6, 25$31 \mathrm{~cm}$. Two chlorite-smectite veins postdate this alteration in the piece: one in the center of the piece and one near the top edge of the piece.

clinopyroxene is nearly 2.0 in all cases (Table 5). Mole fractions of $\mathrm{Fe}^{2+}\left(X_{\mathrm{Fe}^{2+}}=n_{\mathrm{Fe}^{2+}} /\left(n_{\mathrm{Fe}^{2+}}+n_{\mathrm{Mg}}\right)\right.$ appear to range more widely for texturally secondary clinopyroxene than for magmatic clinopyroxene (Fig. 6A). In addition, Ca contents increase from magmatic clinopyroxene ( $38 \%-44 \%$ wollastonite component) through cores of secondary grains $(43 \%-46 \%)$ to secondary rims $(45 \%-50 \%$; Fig. $6 \mathrm{~B})$.
We interpret the secondary clinopyroxene compositions as reflecting exchange with a hydrothermal fluid. The compositional zoning documented in Figure 6 suggests that the rims of the secondary grains and patches reflect more complete exchange, whereas the intermediate compositional characteristics of the cores of these grains and patches imply incomplete exchange.

Replacement of magmatic orthopyroxene, olivine, and oxide near microscopic amphibole veins is typically more extensive than that of clinopyroxene. Orthopyroxene has intercumulus textures in virtually all cases, and these grains are altered to actinolite and/or cummingtonite (PI. 1, Fig. 5; Table 3). Rounded cumulate olivine grains are replaced by intergrowths of talc and magnetite \pm cummingtonite that are overgrown by actinolite (Pl. 1, Fig. 6). No secondary orthopyroxene or olivine has been noted. Oxide grains near microscopic amphibole veins range from composite grains of ilmenite and magnetite to skeletal ilmenite relicts in which magnetite has been replaced by ferro-hornblende (Table 3 ).

\section{Macroscopic Veins and Associated Alteration Macroscopic Amphibole Veins}

Macroscopic amphibole veins crosscut microscopic amphibole veins and associated alteration (Pl. 2, Fig. 1; Table 1). They are light green to blue green and range from wispy, discontinuous features to straight-walled veins continuous throughout individual core pieces. In hand specimen, macroscopic amphibole veins are difficult to identify, especially in strongly altered gabbros. A total of 44 macroscopic amphibole veins were recorded in Hole 894G (Manning et al., this volume). Figure 7 shows that veins of this type are most abundant in the upper $20 \mathrm{~m}$ of the core, or from $\sim 20$ to $\sim 80 \mathrm{mbsf}$ (Manning et al., this volume).

Widths are typically $<1 \mathrm{~mm}$ when measured macroscopically (Fig. 2B), though they may exhibit strong microscopic variability in width depending on the host magmatic mineral. Plate 2, Fig. 2, shows that these veins are narrow where they cut plagioclase grains, but they widen considerably where transecting pyroxene grains. In addition, optical petrography reveals that macroscopic amphibole "veins" are in some cases composites of numerous tightly clustered thinner veins

Table 4. Representative plagioclase compositions, Hole 894G.

\begin{tabular}{|c|c|c|c|c|c|c|}
\hline \multirow{6}{*}{$\begin{array}{l}\text { Core, section: } \\
\text { Piece no.: } \\
\text { Analysis no.: } \\
\text { Name: }\end{array}$} & \multicolumn{2}{|c|}{ Magmatic } & \multicolumn{2}{|c|}{$\begin{array}{l}\text { Associated with } \\
\text { micro-amp veins }\end{array}$} & \multicolumn{2}{|c|}{$\begin{array}{l}\text { Associated with } \\
\text { macro-amp veins }\end{array}$} \\
\hline & Core & $\operatorname{Rim}$ & Early amp & Late amp & Ca-poor & Ca-rich \\
\hline & $17 \mathrm{R}-2$ & 17R-2 & $4 R-2$ & $9 \mathrm{R}-3$ & $17 \mathrm{R}-2$ & $17 \mathrm{R}-2$ \\
\hline & 1B & IB & 10 & $5 \mathrm{E}$ & IB & IB \\
\hline & 8 & 9 & 19 & 16 & 39 & 40 \\
\hline & Lab & Lab & Lab & Olig & Olig & Byt \\
\hline $\mathrm{SiO}_{2}$ & 52.63 & 53.93 & 53.51 & 61.22 & 64.15 & 46.69 \\
\hline $\mathrm{TiO}_{2}^{2}$ & 0.02 & 0.01 & 0.07 & 0.00 & 0.03 & 0.00 \\
\hline $\mathrm{Al}_{2} \mathrm{O}_{3}$ & 29.46 & 28.57 & 28.53 & 24.03 & 21.52 & 32.20 \\
\hline $\mathrm{Cr}_{2} \mathrm{O}_{3}^{3}$ & 0.00 & 0.00 & 0.04 & 0.02 & 0.00 & 0.00 \\
\hline $\mathrm{Fe}_{2} \mathrm{O}_{3}$ & 0.36 & 0.44 & 0.67 & 0.25 & 0.22 & 0.22 \\
\hline $\mathrm{MgO}^{3}$ & 0.03 & 0.02 & 0.07 & 0.10 & 0.19 & 0.00 \\
\hline $\mathrm{MnO}$ & 0.03 & 0.00 & 0.02 & 0.02 & 0.00 & 0.05 \\
\hline $\mathrm{CaO}$ & 12.74 & 11.95 & 12.15 & 5.60 & 3.64 & 17.64 \\
\hline $\mathrm{Na}_{2} \mathrm{O}$ & 4.56 & 5.03 & 4.69 & 8.38 & 10.04 & 1.68 \\
\hline $\mathrm{K}_{2} \mathrm{O}$ & 0.04 & 0.01 & 0.02 & 0.09 & 0.05 & 0.02 \\
\hline \multirow[t]{2}{*}{ Total } & 99.87 & 99.98 & 99.75 & 99.70 & 99.84 & 98.50 \\
\hline & \multicolumn{6}{|c|}{ Atoms per 8 oxygens } \\
\hline $\mathrm{Si}$ & 2.397 & 2.447 & 2.439 & 2.730 & 2.844 & 2.184 \\
\hline $\mathrm{Ti}$ & 0.001 & 0.000 & 0.002 & 0.000 & 0.001 & 0.000 \\
\hline $\mathrm{Al}$ & 1.582 & 1.528 & 1.533 & 1.263 & 1.125 & 1.776 \\
\hline $\mathrm{Cr}$ & 0.000 & 0.000 & 0.001 & 0.001 & 0.000 & 0.000 \\
\hline $\mathrm{Fe}^{3+}$ & 0.006 & 0.008 & 0.012 & 0.004 & 0.004 & 0.004 \\
\hline $\mathrm{Mg}$ & 0.002 & 0.002 & 0.005 & 0.007 & 0.013 & 0.000 \\
\hline $\mathrm{Mn}$ & 0.001 & 0.000 & 0.001 & 0.001 & 0.000 & 0.002 \\
\hline $\mathrm{Ca}$ & 0.622 & 0.581 & 0.593 & 0.268 & 0.173 & 0.884 \\
\hline $\mathrm{Na}$ & 0.403 & 0.443 & 0.414 & 0.724 & 0.863 & 0.152 \\
\hline K & 0.002 & 0.001 & 0.001 & 0.005 & 0.003 & 0.001 \\
\hline Total & 5.014 & 5.010 & 5.000 & 5.002 & 5.025 & 5.004 \\
\hline
\end{tabular}

Notes: All Fe assumed to be $\mathrm{Fe}^{3+}$. Amp = amphibole, micro-amp = microscopic amphibole, macro-amp = macroscopic amphibole, byt $=$ bytownite, lab $=$ labradorite, and olig = oligoclase. 


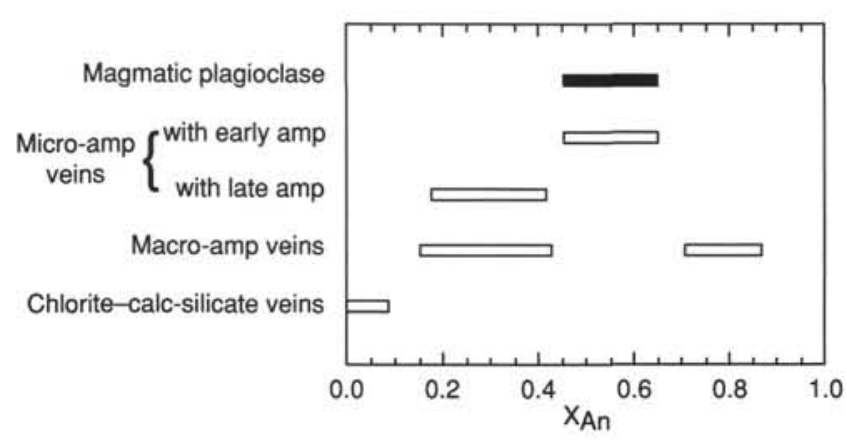

Figure 5. Variation in mole fractions of anorthite in plagioclase $\left(\mathrm{X}_{\mathrm{An}}\right)$ in Hole $894 \mathrm{G}$ as a function of vein or alteration type. Bars show range in analyzed compositions. Micro-amp = microscopic amphibole, and Macro-amp $=$ macroscopic amphibole.

(e.g., Pl. 2, Fig. 3). The only other mineral grains found in these veins are angular to rounded pieces of magmatic plagioclase occasionally broken from host crystals. Each macroscopic amphibole vein examined in thin section exhibits local alteration of wall-rock plagioclase to inclusion-rich plagioclase with lower relief and a different optical orientation (Pl. 2, Fig. 4). However, this alteration is limited: $>95 \%$ of plagioclase grains crosscut by macroscopic amphibole veins are optically indistinguishable from magmatic plagioclase. Because of the limited plagioclase alteration in the wallrock, alteration halos about these veins are expressed only as somewhat more extensive amphibole replacement of magmatic clinopyroxene near veins.

Macroscopic amphibole veins are filled by green to blue-green calcic amphibole. They are compositionally distinct from earlier microscopic vein amphiboles in that their compositions appear to define two groups (Table 6; Fig. 3): Al-rich compositions ( ${ }^{\mathrm{IV}} \mathrm{Al} \geq 1.0$ ), and $\mathrm{Al}$-poor compositions $\left({ }^{\mathrm{IV}} \mathrm{Al} \leq 0.75\right)$. We tentatively conclude that the two groups define a compositional gap in the vein-filling calcic amphiboles, similar to that observed in late calcic amphibole veins in Tertiary gabbros in East Greenland (Bird et al., 1988). The vein amphiboles are also distinct from microscopic vein amphiboles in their more uniform $X_{\mathrm{Mg}}$ and low Ti contents (Fig. 3).

Local inclusion-rich, secondary plagioclase at the margins of macroscopic amphibole veins or as pieces within the veins is compositionally complex (Table 4). Figure 5 illustrates that oligoclaseandesine compositions coexist with extremely calcic secondary plagioclase $\left(X_{\mathrm{An}}>0.70\right)$. Metamorphic clinopyroxene is not associated with macroscopic amphibole veins; otherwise, mafic phases in the wallrock near macroscopic amphibole veins are altered to the same minerals as they are near microscopic amphibole veins, though the degree of replacement is typically greater.

\section{Chlorite Veins}

Two types of chlorite-bearing veins were identified: chlorite-calcsilicate veins and chlorite-smectite veins. In each group, veins are typically characterized by chlorite-lined vein walls and with vein centers filled by either calc-silicates (prehnite and epidote) or smectite. The two types were subdivided based on macroscopic mineralogical criteria (Manning et al., this volume): chlorite-bearing veins containing smectite, but no macroscopic prehnite or epidote, were classified as chlorite-smectite veins; those containing chlorite only or chlorite + calc-silicates were classified as chlorite-calc-silicate veins, even if a clay-like phase was present. However, this macroscopic distinction between chlorite-calc-silicate veins and chlorite-smectite veins often proved arbitrary for two reasons. First, smectite and mixed-layer clays commonly occur as late vein fill in chlorite-calc-silicate veins. And second, thin-section examination frequently revealed micro-
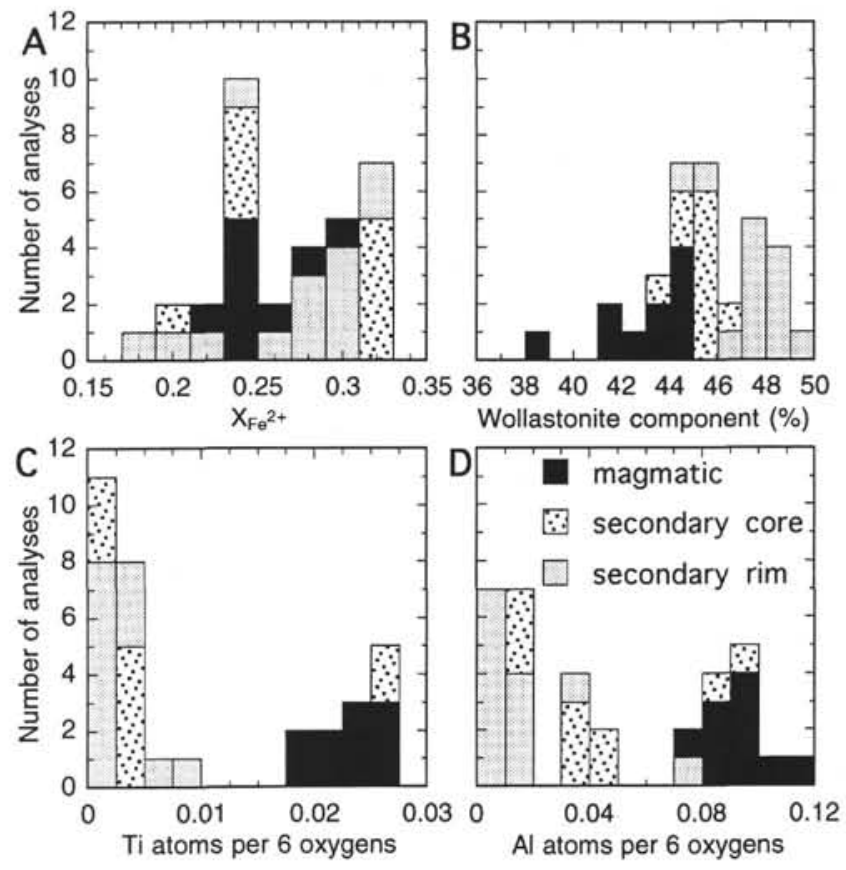

Figure 6. A-D. Histograms showing compositional distinctions between magmatic and secondary clinopyroxenes.

scopic prehnite or epidote in features identified as chlorite-smectite veins. Moreover, mutual crosscutting relations exist between the two chlorite-bearing vein types, although chlorite-calc-silicate veins are predominantly older (Table 1). These observations therefore suggest that the two chlorite-bearing vein types are more mineralogically similar on a microscopic scale than macroscopic observation suggests, and that they overlapped in terms of time of formation.

\section{Chlorite-Calc-silicate Veins}

Chlorite-calc-silicate (CCS) veins are dark green to black. The diagnostic mineral is chlorite. In approximately half of observed occurrences, paragenetically later botryoidal prehnite and/or epidote fill vein centers (Pl. 3, Fig. 1). Chlorite is absent from the vein assemblage in only a few instances in which the veins are completely filled by prehnite and epidote. Vein centers containing calc-silicates may be vuggy and range from discontinuous lenticular pods to throughgoing vein fill. Other associated vein-filling minerals include minor actinolite intergrown with chlorite, sphene, sphalerite, and pyrite. Brecciated clasts of wallrock plagioclase within the veins are overgrown by translucent, inclusion-free albite, whereas clasts of clinopyroxene may be replaced by secondary clinopyroxene or overgrown by actinolite. Wallrock alteration near these veins is typically more extensive than that associated with amphibole veins. These alteration halos have a mean width of $3 \mathrm{~mm}$ (Manning et al., this volume). The alteration consists of replacement of magmatic plagioclase by secondary plagioclase and epidote in white zones in hand specimen (Fig. 8). In thin section these altered zones are inclusion-rich translucent secondary plagioclase with low relief (Pl. 3, Fig. 1). In addition, clinopyroxene is replaced by actinolite, and where relict magmatic clinopyroxene is preserved, exsolution lamellae of orthopyroxene are completely altered to chlorite. Wall-rock orthopyroxene and olivine are replaced by chlorite, actinolite and magnetite. These zones of alteration may extend up to $\sim 1 \mathrm{~cm}$ away from vein margins. Veins of this type commonly display textures suggesting multiple reopening and filling by later vein types. 
Table 5. Representative compositions of magmatic and metamorphic clinopyroxene, Hole 894G.

\begin{tabular}{|c|c|c|c|c|c|c|c|}
\hline & \multicolumn{2}{|c|}{ Magmatic clinopyroxene } & \multicolumn{5}{|c|}{ Metamorphic clinopyroxene } \\
\hline & $\begin{array}{c}\text { Exsolved } \\
\text { grain }\end{array}$ & $\begin{array}{c}\text { Exsolved } \\
\text { grain }\end{array}$ & $\begin{array}{c}\text { Core, } \\
\text { translucent } \\
\text { patch }\end{array}$ & $\begin{array}{c}\text { Core, } \\
\text { translucent } \\
\text { patch }\end{array}$ & $\begin{array}{c}\text { Rim, } \\
\text { translucent } \\
\text { patch }\end{array}$ & $\begin{array}{c}\text { Rim, } \\
\text { granular grain }\end{array}$ & $\begin{array}{c}\text { Rim, } \\
\text { granular grain }\end{array}$ \\
\hline Core, section: & $17 R-1$ & 17R-2 & 18R-2 & 9R-3 & $9 \mathrm{R}-3$ & $13 \mathrm{R}-1$ & 17R-2 \\
\hline Piece no.: & 6 & IB & 3 & $5 \mathrm{E}$ & $5 \mathrm{E}$ & $11 \mathrm{~B}$ & IB \\
\hline Analysis no.: & 65 & 26 & 47 & 31 & 33 & 30 & 33 \\
\hline $\mathrm{SiO}_{2}$ & 52.17 & 51.50 & 52.41 & 53.01 & 54.20 & 53.88 & 53.79 \\
\hline $\mathrm{TiO}_{2}$ & 0.80 & 0.94 & 0.18 & 0.19 & 0.03 & 0.00 & 0.04 \\
\hline $\mathrm{Al}_{2} \mathrm{O}_{3}$ & 1.86 & 1.99 & 1.04 & 1.09 & 0.12 & 0.12 & 0.39 \\
\hline $\mathrm{Cr}_{2} \mathrm{O}_{3}$ & 0.14 & 0.00 & 0.08 & 0.09 & 0.02 & 0.01 & 0.00 \\
\hline $\mathrm{FeO}$ & 10.54 & 9.12 & 8.07 & 10.63 & 9.03 & 7.02 & 6.42 \\
\hline $\mathrm{MgO}$ & 14.27 & 14.56 & 14.80 & 13.24 & 13.03 & 14.66 & 14.87 \\
\hline $\mathrm{MnO}$ & 0.26 & 0.32 & 0.26 & 0.38 & 0.36 & 0.23 & 0.34 \\
\hline $\mathrm{CaO}$ & 20.05 & 21.03 & 21.85 & 21.48 & 23.88 & 23.36 & 24.65 \\
\hline $\mathrm{Na}_{2} \mathrm{O}$ & 0.29 & 0.34 & 0.38 & 0.27 & 0.07 & 0.02 & 0.12 \\
\hline $\mathrm{K}_{2} \mathrm{O}$ & 0.00 & 0.00 & 0.02 & 0.00 & 0.00 & 0.00 & 0.01 \\
\hline Total & 100.38 & 99.80 & 99.10 & 100.37 & 100.74 & 99.29 & 100.63 \\
\hline \multicolumn{8}{|c|}{ Atoms per 6 oxygens } \\
\hline $\mathrm{Si}$ & 1.943 & 1.927 & 1.967 & 1.981 & 2.012 & 2.009 & 1.984 \\
\hline $\mathrm{Ti}$ & 0.022 & 0.026 & 0.005 & 0.005 & 0.001 & 0.000 & 0.001 \\
\hline Al & 0.082 & 0.088 & 0.046 & 0.048 & 0.005 & 0.005 & 0.017 \\
\hline $\mathrm{Cr}$ & 0.004 & 0.000 & 0.002 & 0.003 & 0.001 & 0.000 & 0.000 \\
\hline $\mathrm{Fe}^{3+}$ & 0.004 & 0.031 & 0.034 & 0.000 & 0.000 & 0.000 & 0.022 \\
\hline $\mathrm{Fe}^{2+}$ & 0.325 & 0.254 & 0.219 & 0.332 & 0.280 & 0.219 & 0.176 \\
\hline $\mathrm{Mg}$ & 0.792 & 0.812 & 0.828 & 0.738 & 0.721 & 0.814 & 0.817 \\
\hline $\mathrm{Mn}$ & 0.008 & 0.010 & 0.008 & 0.012 & 0.011 & 0.007 & 0.011 \\
\hline $\mathrm{Ca}$ & 0.800 & 0.843 & 0.879 & 0.860 & 0.950 & 0.933 & 0.974 \\
\hline $\mathrm{Na}$ & 0.021 & 0.025 & 0.027 & 0.020 & 0.005 & 0.001 & 0.009 \\
\hline K & 0.000 & 0.000 & 0.001 & 0.000 & 0.000 & 0.000 & 0.000 \\
\hline Total & 4.002 & 4.016 & 4.018 & 3.998 & 3.986 & 3.989 & 4.011 \\
\hline
\end{tabular}

Note: $\mathrm{Fe}^{3+}$ calculated by charge balance.

In all instances in which crosscutting relations were observed, chlorite-calc-silicate veins are younger than both microscopic amphibole veins and macroscopic amphibole veins (Table 1). Chloritecalc-silicate veins range from discontinuous and anastomosing to straight, throughgoing features in parallel sets (Fig. 8). Several intervals of densely clustered vein arrays with short segment lengths and local abrupt changes in orientation and minor cataclasis of wallrock were noted (e.g., Fig. 8); however, chlorite-calc-silicate veins dominantly occur as discrete features with a strong preferred orientation (see below). Chlorite-calc-silicate veins are voluminous, with 404 individual veins noted in Hole 894G. Like macroscopic amphibole veins, they appear to be most prevalent in the upper $20 \mathrm{~m}$ of the core (Fig. 7), that is, between 20 and 80 mbsf (Manning et al., this volume). Widths are typically $<1 \mathrm{~mm}$ (Fig. 2C).

Representative reconnaissance mineral compositions are given in Table 7. Early chlorites lining vein walls are silica-rich Fe-Al clinochlores in the terminology of Bayliss (1975), with $n_{\mathrm{Si}}=6.1-6.2$ per 28 anhydrous oxygens and $X_{\mathrm{Fe}}=0.67-0.75$ (Table 7). Texturally later layer silicates occur in vein centers and have higher $\mathrm{Si}$ and $\mathrm{Ca}$ contents ( $n_{\mathrm{Si}}=6.2-6.7$ and $n_{\mathrm{Ca}}=0.02-0.07$ per 28 anhydrous oxygens). We interpret these to be interlayered chlorite and smectite based on the similarity of their compositions to the chlorite/smectite of the Point Sal ophiolite (Bettison and Schiffman, 1988). Prehnite is typically unzoned and is low in $\mathrm{Fe}^{3+}\left(n_{\mathrm{Fe}^{3+}}=0.050-0.141\right.$ per 11 anhydrous oxygens, assuming all $\mathrm{Fe}$ is $\mathrm{Fe}^{3+}$ ). By contrast, epidotes are commonly zoned from $\mathrm{Fe}^{3+}$-rich cores to $\mathrm{Al}$-rich rims (Table 7). Secondary plagioclase replacement of magmatic plagioclase in veins and wall-rock, as well as inclusion-free overgrowths on plagioclase clasts are in all cases albite $\left(X_{\mathrm{An}}<0.05\right.$; Fig. 5; Table 7).

\section{Chlorite-Smectite Veins}

Chlorite-smectite veins have variable colors, including green, light yellow green, and brown. They are distinguished on the basis of soft green, yellow, or brown smectites and mixed layer clays in vein centers, surrounded by pale green to yellow green chlorite (PI. 3, Fig. 2). Late calcite and zeolites commonly fill residual open space in the centers of chlorite-smectite veins (Pl. 3, Fig. 2). Rounded plagioclase clasts altered to albite are abundant. Wallrock plagioclase may be altered to white inclusion-rich albite (Pl. 3, Fig. 3); however, alteration halos up to several millimeters from these veins (Fig. 9) are sporadic throughout the core, suggesting that alteration of wallrock plagioclase is not as well developed as that associated with chlorite-calcsilicate veins. Clinopyroxene in the wall-rock hosting chlorite-smectite veins is strongly altered to chlorite and smectite, which can be seen as dark patches up to several centimeters from the veins (Fig. 9); the extent of replacement is typically so great that clinopyroxene grains appear optically opaque in thin section (Pl. 3, Fig. 4). Olivine and orthopyroxene in the wall-rock are commonly pseudomorphed by yellow-brown clay. Like clinopyroxene, the alteration of these phases is manifested macroscopically as dark green to yellow-green patches up to $1 \mathrm{~cm}$ from chlorite-smectite veins (Fig. 9).

A total of 583 chlorite-smectite veins were identified in the core, making them the most abundant of the macroscopic types. These veins always crosscut microscopic and macroscopic amphibole veins (Pl. 3, Fig. 3; Table 1). They usually crosscut chlorite-calc-silicate veins as well, although in three cases macroscopic relations suggest the reverse (Table 1). Figure 7 illustrates that they occur throughout the core, showing large fluctuations in abundance, but no concentration in a particular portion of Hole 894G. Like other macroscopic vein types, chlorite-smectite veins are typically $<1 \mathrm{~mm}$ wide (Fig. 2D). Layer silicates in these veins have $n_{\mathrm{Si}}=6.2-6.7$ atoms per 28 anhydrous oxygens (Table 7), consistent with interlayered chlorite/ smectite (Bettison and Schiffman, 1988).

\section{Zeolite-Calcite Veins}

White veins filled by zeolite and calcite are the youngest features observed in Hole 894G (Table 1). Similar in width to the other macroscopic vein types (Fig. 2E), they are uncommon ( 9 veins in Hole 
894G) and sporadic (Fig. 7). Limited study of these features indicates that the veins are filled by either calcite or zeolite, but rarely both. Gabbroic host rocks display little wall-rock alteration near these veins, implying limited water-rock reaction at the time of zeolite-calcite vein formation. As noted above, both zeolites and calcite occur as late alteration in residual pore space in earlier vein types.

\section{Temperatures of Fracture-controlled Metamorphism}

Metamorphic mineral assemblages associated with each vein type are summarized in Table 8.

\section{Microscopic Veins}

The earliest microscopic amphibole veins are predominantly responsible for replacement of mafic magmatic minerals by calcic amphibole ranging continuously from actinolite to magnesio-hornblende, clinopyroxene, magnetite, talc, and cummingtonite. Magmatic plagioclase shows only limited alteration to oligoclase-andesine where there is petrographic evidence for a more prolonged alteration event. These observations are consistent with the development of the microscopic amphibole vein network and associated alteration in the amphibolite facies, locally continuing to the transition from greenschist to amphibolite facies. The experimental studies of Liou et al. (1974) and Spear (1981) provide broad limits of $\sim 550^{\circ}$ to in excess of $800^{\circ} \mathrm{C}$ for amphibolite-facies assemblages, assuming oxygen fugacities corresponding to equilibrium among quartz, fayalite, and magnetite (QFM), and $1 \mathrm{~kb}$ total pressure. This pressure is appropriate given the inferred depth of 2-3 km below seafloor for Hole 894G gabbros. Where metamorphism continued into the greenschist-amphibolite transition, temperatures may have been as low as $450^{\circ} \mathrm{C}$ (Liou et al., 1974).

Clinopyroxene compositions can be used to estimate more quantitatively the temperatures of metamorphism associated with microscopic amphibole veins (e.g., Manning and Bird, 1986). However, the granular to patchy textures (Pl. 1) and zoning (Fig. 6) of secondary clinopyroxene make it difficult to demonstrate textural and exchange equilibrium with certainty. To minimize this problem, we considered only rim compositions of secondary clinopyroxene coexisting with calcic amphibole. Temperatures were calculated from projected quadrilateral compositions using the calibration of Anderson et al. (1993) and assuming a pressure of $1 \mathrm{~kb}$. Varying assumed pressure between $1 \mathrm{~atm}$ and $2 \mathrm{~kb}$ leads to calculated temperature differences of only $\pm 1^{\circ} \mathrm{C}$.

Magmatic clinopyroxene compositions record temperatures of $875^{\circ}-1100^{\circ} \mathrm{C}$ (Fig. 10). This reflects reequilibration below the solidus during exsolution of Ca-poor pyroxene upon cooling. Rims of metamorphic clinopyroxenes suggest temperatures of up to $750^{\circ} \mathrm{C}$ (Fig. 10), with most compositions implying amphibolite-facies temperatures of $600^{\circ}-750^{\circ} \mathrm{C}$. In addition, lower temperatures of the uppermost greenschist to transitional greenschist-amphibolite facies $\left(450^{\circ}-525^{\circ} \mathrm{C}\right)$ are recorded principally by coarse-grained pegmatitic Sample 147-894G-9R-5, Piece 3, 88-91 cm, consistent with the observation that coarse-grained rocks record alteration to lower metamorphic grades (see above). Patches of secondary clinopyroxene adjacent to magmatic clinopyroxene or secondary grain centers (cores; Fig. 10) appear to record temperatures of $725^{\circ}-900^{\circ} \mathrm{C}$, between those of magmatic grains and metamorphic rims. This is consistent with their intermediate compositions (Fig. 6). Because they do not lie at grain edges in contact with demonstrably secondary phases, we suggest that these temperatures are apparent rather than real, reflecting incomplete exchange of components between magmatic clinopyroxene and the hydrothermal fluid phase.

Temperatures derived from single-pyroxene thermometry are typically taken to be minima because they do not account explicitly for compositional constraints imposed by coexisting magmatic $\mathrm{Ca}$-poor
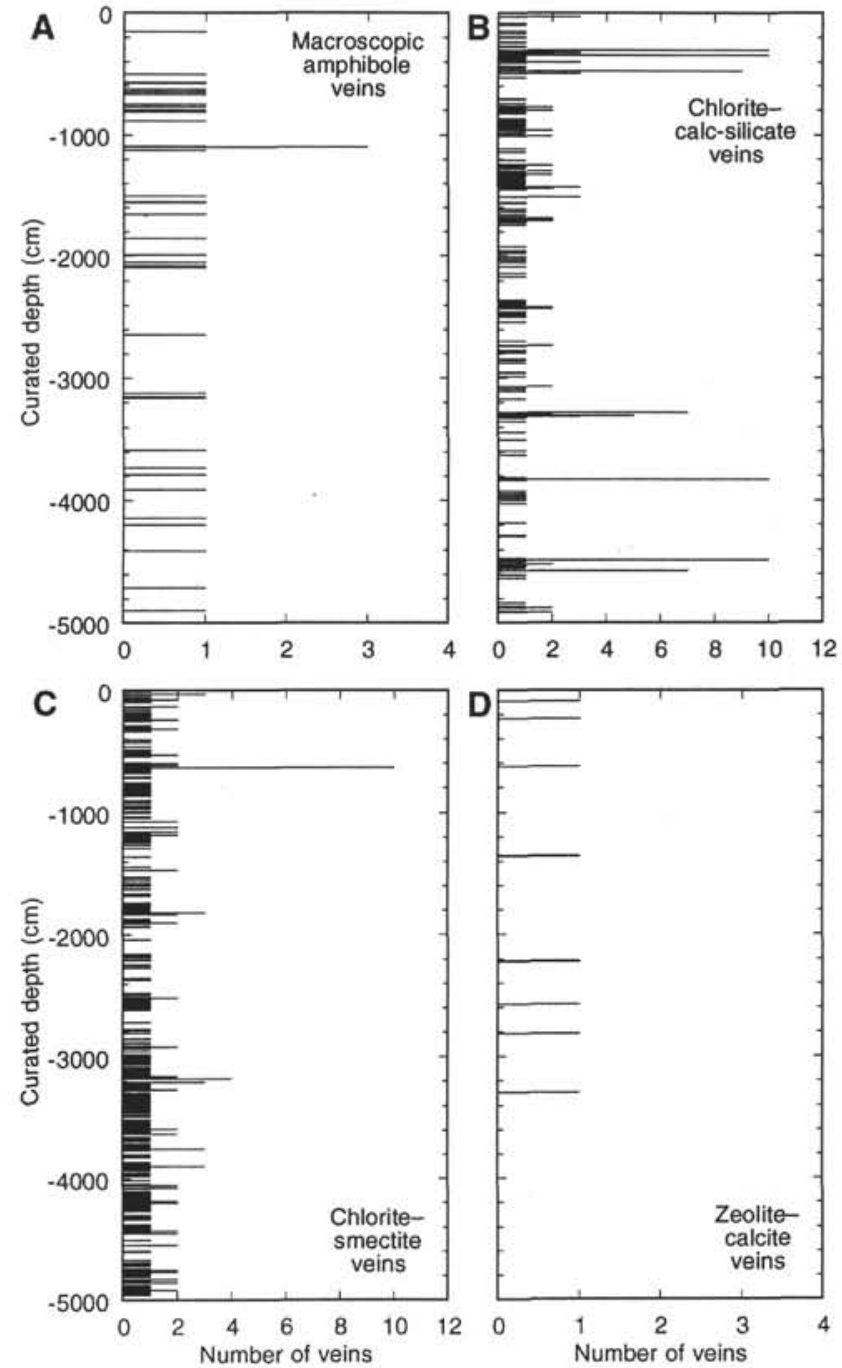

Figure 7. A-D. Vein locations in core from Hole 894G. Locations are shown with respect to curated depth rather than expanded depth below seafloor to more accurately convey the relative abundance of the veins.

pyroxene (e.g., Lindsley, 1983); however, magmatic clinopyroxenes coexist with Ca-poor clinopyroxene and secondary rims coexist with calcic amphibole, which is less calcic than the clinopyroxene (Tables $1,5)$. This suggests that, although not derived from exchange equilibria involving these additional phases, temperatures are unlikely to have been significantly greater than those inferred. Thus, metamorphic temperatures from metamorphic clinopyroxene compositions suggest that formation of microscopic amphibole veins and associated alteration occurred principally in the amphibolite facies at temperatures of $600^{\circ}-750^{\circ} \mathrm{C}$, and continued to lower temperatures of the greenschist-amphibolite transition where favorable conditions such as coarse grain size existed.

\section{Macroscopic Veins}

Mineral assemblages found in macroscopic amphibole veins and associated alteration include calcic amphiboles displaying a compositional gap from ${ }^{\mathrm{IV}} \mathrm{Al}=\sim 0.75$ to 1.0 and plagioclase ranging from magmatic labradorite to oligoclase-andesine coexisting with Ca-rich bytownites. Such assemblages are typical of the greenschist-amphib- 
Table 6. Representative compositions of amphiboles in macroscopic amphibole veins and associated alteration, Hole 894G.

\begin{tabular}{|c|c|c|c|c|c|c|}
\hline \multirow[b]{3}{*}{$\begin{array}{l}\text { Analysis no.: } \\
\text { Name: }\end{array}$} & \multicolumn{4}{|c|}{ 147-894G-4R-2, Piece 3} & \multicolumn{2}{|c|}{ 147-894G-17R-2, Piece 1B } \\
\hline & $\begin{array}{l}\text { With olig in } \\
\text { wallrock } \\
\text { plag at vein } \\
\text { margin }\end{array}$ & $\begin{array}{l}\text { Early prism } \\
\text { at vein } \\
\text { margin }\end{array}$ & $\begin{array}{l}\text { Early prism } \\
\text { in vein } \\
\text { center }\end{array}$ & $\begin{array}{l}\text { Late } \\
\text { vein } \\
\text { fill }\end{array}$ & $\begin{array}{c}\text { Plag } \\
\text { wallrock }\end{array}$ & $\begin{array}{c}\text { Cpx } \\
\text { wallrock }\end{array}$ \\
\hline & $\begin{array}{c}33 \\
\text { Mg-hbd }\end{array}$ & $\begin{array}{c}30 \\
\text { Mg-hbd }\end{array}$ & $\begin{array}{c}29 \\
\text { Act-hbd }\end{array}$ & $\begin{array}{l}28 \\
\text { Act }\end{array}$ & $\begin{array}{c}19 \\
\text { Mg-hbd }\end{array}$ & $\begin{array}{c}29 \\
\text { Act-hbd }\end{array}$ \\
\hline $\begin{array}{l}\mathrm{SiO}_{2} \\
\mathrm{MgO} \\
\mathrm{Na}_{2} \mathrm{O} \\
\mathrm{Al}_{2} \mathrm{O}_{3} \\
\mathrm{FeO} \\
\mathrm{MnO} \\
\mathrm{Cr}_{2} \mathrm{O}_{3} \\
\mathrm{~K}_{2} \mathrm{O} \\
\mathrm{CaO} \\
\mathrm{TiO}_{2} \\
\text { Total }\end{array}$ & $\begin{array}{r}48.55 \\
13.74 \\
1.27 \\
7.47 \\
14.33 \\
0.17 \\
0.00 \\
0.08 \\
11.79 \\
0.51 \\
97.89\end{array}$ & $\begin{array}{r}48.07 \\
13.46 \\
1.42 \\
6.97 \\
15.13 \\
0.20 \\
0.00 \\
0.15 \\
11.81 \\
0.64 \\
97.86\end{array}$ & $\begin{array}{r}51.54 \\
15.49 \\
0.78 \\
4.83 \\
12.75 \\
0.20 \\
0.00 \\
0.03 \\
11.85 \\
0.37 \\
97.84\end{array}$ & $\begin{array}{r}55.23 \\
17.28 \\
0.18 \\
1.28 \\
11.03 \\
0.25 \\
0.02 \\
0.02 \\
12.12 \\
0.18 \\
97.60\end{array}$ & $\begin{array}{r}45.07 \\
13.04 \\
1.98 \\
10.69 \\
14.49 \\
0.25 \\
0.00 \\
0.11 \\
11.82 \\
0.21 \\
97.33\end{array}$ & $\begin{array}{r}51.42 \\
15.40 \\
0.79 \\
4.91 \\
12.17 \\
0.19 \\
0.00 \\
0.09 \\
12.02 \\
0.59 \\
96.84\end{array}$ \\
\hline \multicolumn{7}{|c|}{ Atoms per 23 anhydrous oxygens } \\
\hline $\mathrm{Si}$ & 7.029 & 7.009 & 7.376 & 7.865 & 6.575 & 7.385 \\
\hline iv $\mathrm{Al}$ & 0.971 & 0.991 & 0.624 & 0.135 & 1.425 & 0.615 \\
\hline${ }^{\mathrm{V}} \mathrm{Al}$ & 0.304 & 0.207 & 0.191 & 0.080 & 0.414 & 0.216 \\
\hline $\mathrm{Fe}^{2+}$ & 1.367 & 1.465 & 1.199 & 1.277 & 1.221 & 1.247 \\
\hline $\mathrm{Fe}^{3+}$ & 0.368 & 0.380 & 0.327 & 0.036 & 0.547 & 0.214 \\
\hline $\mathrm{Mg}$ & 2.965 & 2.925 & 3.304 & 3.667 & 2.835 & 3.296 \\
\hline $\mathrm{Mn}$ & 0.021 & 0.025 & 0.024 & 0.030 & 0.031 & 0.023 \\
\hline $\mathrm{Ti}$ & 0.056 & 0.070 & 0.040 & 0.019 & 0.023 & 0.064 \\
\hline $\mathrm{Ca}$ & 1.829 & 1.845 & 1.817 & 1.849 & 1.848 & 1.850 \\
\hline $\mathrm{Na}$ & 0.356 & $0.40 \mathrm{I}$ & 0.216 & 0.050 & 0.560 & 0.220 \\
\hline K & 0.015 & 0.028 & 0.005 & 0.004 & 0.020 & 0.016 \\
\hline $\mathrm{Cr}$ & 0.000 & 0.000 & 0,000 & 0.002 & 0.000 & 0.000 \\
\hline Total & 15.280 & 15.347 & 15.124 & 15.016 & 15.499 & 15.147 \\
\hline
\end{tabular}

Notes: $\mathrm{Fe}^{3+}$ is midpoint between minimum and maximum calculated by charge balance. $\mathrm{Cpx}=$ clinopyroxene, plag $=$ plagioclase, olig $=$ oligoclase, act $=$ actinolite, act $-\mathrm{hbd}=$ actinolitic hornblende, and $\mathrm{Mg}$-hbd = magnesio-hornblende.

olite transition to the lower amphibolite-facies (Maruyama et al., 1983); that is, temperatures of $\sim 450^{\circ}$ to $600^{\circ} \mathrm{C}$ assuming low $\mathrm{CO}_{2}$ contents (Liou et al., 1974). This is consistent with the absence of greenschist-facies minerals such as chlorite, epidote, prehnite, or albite coexisting with $\mathrm{Al}$-poor calcic amphiboles in or near these veins.

Chlorite-calc-silicate veins and associated alteration record metamorphic conditions of the greenschist facies, based on coexisting chlorite, actinolite, albite, prehnite, and epidote (e.g., Liou et al., 1985). Maximum temperatures of this assemblage are $550^{\circ} \mathrm{C}$ based on the breakdown of chlorite in basaltic bulk compositions at $1 \mathrm{~kb}$ and QFM, and $450^{\circ} \mathrm{C}$ based on the upper stability of prehnite at $1 \mathrm{~kb}$ in pure $\mathrm{H}_{2} \mathrm{O}$ (Helgeson et al., 1978; Bird et al., 1986). Minimum temperatures for stable coexistence of this assemblage are difficult to ascertain, but are probably $\sim 250^{\circ}$ to $300^{\circ} \mathrm{C}$, below which actinolite should not coexist with albite (Liou et al., 1985). Temperatures of formation of chlorite-smectite and zeolite-calcite veins were $<300^{\circ} \mathrm{C}$ based on the presence of mixed-layer clays and the upper thermal stabilities of Ca-Na zeolites (e.g., Frey et al., 1991).

\section{ORIENTATIONS OF MACROSCOPIC VEINS}

\section{Background}

The orientations of hydrothermal veins provide additional information about the structural and metamorphic evolution of the gabbros. Random orientations may result from the effects of local stress regimes, as might be expected for the cooling and thermal contraction of an initially isotropic body. Such an origin has been proposed for veins in the lower portions of the sheeted dikes from Hole 504B (Shipboard Scientific Party, 1992). Random orientations may also arise in the process zones of nearby normal faults (Agar, 1994). Systematic non-random orientations, on the other hand, would be expected to record regional stress fields during fracture opening (e.g., Agar,
$1990,1994)$. Comparing these orientations to those likely to be associated with tectonic events experienced by the gabbros would thus constrain the relative controls on brittle fracturing and vein formation.

Four effects may bias the distribution of observed vein orientations in core samples from a borehole. First, drilling a "onedimensional" vertical borehole greatly reduces the likelihood of encountering vertical or steeply dipping features (by an amount proportional to the cosine of the dip for a randomly distributed data set; Terzaghi, 1965; Newmark et al., 1985). In addition, the mechanical aspects of the drilling process lead to breakage of the core into discrete pieces. Traces of hydrothermal minerals were routinely observed on the bottom of polished and spun core pieces at Site 894, suggesting a possible preferential obliteration of shallowly dipping veins. This effect is difficult to quantify. In the first two cases, the set of observed vein orientations are affected whether or not individual pieces can be reoriented with respect to the axis of the borehole. A third bias is introduced when dip data are known only relative to the axis of the borehole, which is the case for most previous studies and for about half of our vein data from Hole 894G. For a randomly distributed set of planes, a histogram of their dips will be biased strongly toward the steeper values by an amount proportional to the sine of their dip, simply as a consequence of the projection (Shipboard Scientific Party, 1992). Finally, a smearing effect, which for a random data set decreases the clustering of a given preferred dip, is introduced on histogram plots if no correction is made for deviation of the borehole from the vertical, or if tectonic rotation has occurred subsequent to formation of the planar features.

The biasing effects outlined above are potentially important for Hole $894 \mathrm{G}$ because (1) it is sited in a faulted block which is thought to have been rotated (MacLeod, Boudier, et al., this volume); and (2) although borehole deviation measurements are only available for the logged interval, they show the borehole to be inclined southwestward at $4^{\circ}-5^{\circ}$ from the vertical at $75-80 \mathrm{mbsf}$ (Célérier et al., this volume), 
and this deviation may have been substantially greater in the lower portions of the borehole (Shipboard Scientific Party, 1993). In the absence of direct information throughout the borehole, this has not been quantified, and we have therefore applied no correction for deviation in this paper unless otherwise noted.

Below, we discuss orientations of macroscopic veins (1) relative to the borehole axis, (2) relative to a common magnetic declination, and (3) relative to FMS results. We limit our discussion to macroscopic veins because no systematic study of microscopic veins has been attempted in core samples, and their small dimensions make them impossible to detect with borehole imaging techniques.

\section{Vein Orientations Relative to the Borehole Axis}

Because core pieces oriented relative to the borehole axis rotate independently in the core barrel, the only vein orientation measurement that can be compared from piece to piece is vein dip. A histogram of the dips of veins relative to the axis of the borehole from 894G $(N=601)$ shows marked preference for moderate to steep dips (Fig. 11), with a mean for all veins of $57.0^{\circ}\left(1 \mathrm{SD}=19.2^{\circ}\right)$. Both chlorite vein types display a similar maximum in dips at $40^{\circ}-65^{\circ}$, with steeper dips common, but shallower dips rare. Comparatively few oriented macroscopic amphibole veins $(N=24)$ are present, but these cluster at somewhat steeper dips than the chlorite veins. All oriented zeolite-calcite veins have dips of $35^{\circ}-70^{\circ}$.

\section{Magnetically Restored Vein Orientations Macroscopic Amphibole Veins}

Macroscopic amphibole veins restored to a common magnetic declination show no preferred orientation (Fig. 12A), varying from steep to shallow dips and having variable strikes. Restoring macroscopic amphibole veins to both a common inclination and declination does not result in any preferred orientation (Fig. 12B). Thus, despite only seven magnetically restored vein orientations, macroscopic amphibole veins can be seen to show no preferred orientation.

\section{Chlorite-Calc-silicate and Chlorite-Smectite Veins}

When restored to a common magnetic declination, both chloritebearing vein types have a strong west-northwest, south-dipping trend (Fig. 13A, B). Chlorite-calc-silicate veins are somewhat more tightly clustered at this orientation than chlorite-smectite veins. If the horizontal component of rotation (northward tilting) occurred after veining, then restoring the data to both a common magnetic inclination of $+46^{\circ}$ (the inclination of the axial dipole field at this latitude) and a common declination direction restores the majority of veins to much nearer the vertical (Fig. 13C).

\section{Zeolite-Calcite Veins}

Only five zeolite-calcite veins could be restored magnetically. Figure 14 shows that these veins have similar strikes to the northwest, with intermediate dips to both the northeast and southwest.

\section{Vein Orientations Compared to FMS Results}

Veins measured in the core are predominantly planar features from the center of the borehole. The planar, low resistivity features identified on the FMS images are thought to be fractures on the borehole wall, whether filled or unfilled by secondary minerals. Because of poor conditions in Hole 894G, the FMS images obtained during logging were of low quality and it has not been possible to match the features on a 1:1 basis; therefore the FMS fracture data set is instead compared with the vein data set from the core over the same depth in-

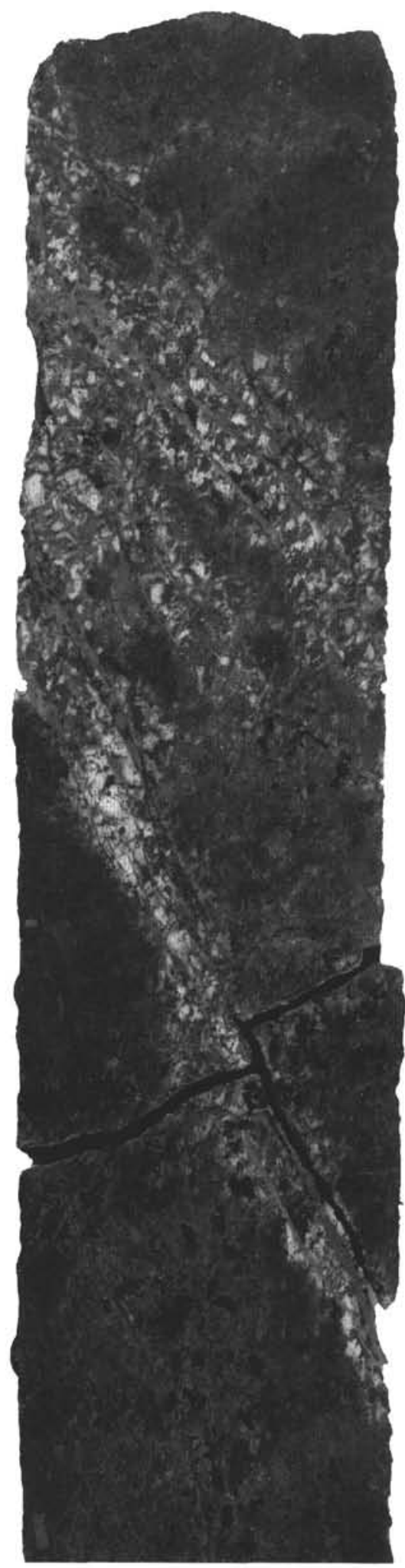

Figure 8. Clustered chlorite-calc-silicate veins with high-angle splays. Sample 147-894G-12R-5, Pieces 7B-D, 41-64 cm. 
Table 7. Representative compositions of minerals in chlorite-calcite-silicate and chlorite-smectite veins, Hole 894G.

\begin{tabular}{|c|c|c|c|c|c|c|c|c|c|}
\hline \multirow{5}{*}{$\begin{array}{l}\text { Core, section: } \\
\text { Piece no.: } \\
\text { Analysis no.: }\end{array}$} & \multicolumn{7}{|c|}{ Chlorite-calcite-silicate veins } & \multicolumn{2}{|c|}{ Chlorite-smectite veins } \\
\hline & $\begin{array}{l}\text { Early chlorite at } \\
\text { vein margin }\end{array}$ & Prehnite & $\begin{array}{l}\text { Epidote } \\
\text { core }\end{array}$ & $\begin{array}{l}\text { Epidote } \\
\text { rim }\end{array}$ & $\begin{array}{l}\text { Chlorite/ } \\
\text { smectite }\end{array}$ & $\begin{array}{l}\text { Chlorite/ } \\
\text { smectite }\end{array}$ & $\begin{array}{l}\text { Albite in } \\
\text { wallrock }\end{array}$ & $\begin{array}{l}\text { Chlorite/ } \\
\text { smectite }\end{array}$ & $\begin{array}{l}\text { Chlorite/ } \\
\text { smectite }\end{array}$ \\
\hline & $6 \mathrm{R}-1$ & $8 \mathrm{R}-1$ & 2R-3 & $2 \mathrm{R}-3$ & $8 R-1$ & $2 R-3$ & $17 R-1$ & $6 \mathrm{R}-1$ & $6 \mathrm{R}-1$ \\
\hline & $4 \mathrm{~A}$ & 10 & 3 & 3 & 10 & 3 & 6 & $4 \mathrm{~A}$ & $4 \mathrm{~A}$ \\
\hline & 25 & 20 & 16 & 17 & 6 & 15 & 62 & 26 & 27 \\
\hline $\mathrm{SiO}_{2}$ & 30.46 & 43.78 & 38.75 & 39.46 & 32.01 & 33.95 & 68.89 & 30.93 & 30.90 \\
\hline $\mathrm{TiO}_{2}^{2}$ & 0.08 & 0.06 & 0.21 & 0.08 & 0.00 & 0.00 & 0.01 & 0.01 & 0.04 \\
\hline $\mathrm{Al}_{2} \mathrm{O}_{3}$ & 16.60 & 22.99 & 25.00 & 28.28 & 15.96 & 15.41 & 18.56 & 16.06 & 15.85 \\
\hline $\mathrm{Cr}_{2} \mathrm{O}_{3}$ & 0.00 & 0.06 & 0.02 & 0.04 & 0.04 & 0.00 & 0.02 & 0.06 & 0.01 \\
\hline $\mathrm{Fe}_{2} \mathrm{O}_{3}$ & & 2.35 & 11.71 & 7.52 & & & 0.07 & & \\
\hline $\mathrm{FeO}$ & 14.35 & & & & 17.94 & 14.44 & & 13.66 & 14.61 \\
\hline $\mathrm{MgO}$ & 23.29 & 0.00 & 0.00 & 0.00 & 21.70 & 22.39 & 0.00 & 23.25 & 22.89 \\
\hline $\mathrm{MnO}$ & 0.22 & 0.08 & 0.11 & 0.04 & 0.26 & 0.20 & 0.01 & 0.21 & 0.25 \\
\hline $\mathrm{CaO}$ & 0.10 & 26.37 & 23.82 & 23.81 & 0.15 & 0.26 & 0.24 & 0.12 & 0.08 \\
\hline $\mathrm{Na}_{2} \mathrm{O}$ & 0.00 & 0.00 & 0.00 & 0.00 & 0.00 & 0.07 & 11.81 & 0.02 & 0.00 \\
\hline $\mathrm{K}_{2} \mathrm{O}$ & 0.00 & 0.02 & 0.02 & 0.00 & 0.00 & 0.00 & 0.02 & 0.00 & 0.00 \\
\hline Total & 85.09 & 95.71 & 99.64 & 99.22 & 88.07 & 86.73 & 99.63 & 84.32 & 84.63 \\
\hline No. oxygens & 28 & 11 & 12.5 & 12.5 & 28 & 28 & 8 & 28 & 28 \\
\hline $\mathrm{Si}$ & 6.208 & 3.022 & 3.011 & 3.024 & 6.401 & 6.737 & 3.022 & 6.334 & 6.337 \\
\hline $\mathrm{Ti}$ & 0.012 & 0.003 & 0.012 & 0.004 & 0.000 & 0.000 & 0.000 & 0.001 & 0.006 \\
\hline $\mathrm{Al}$ & 3.986 & 1.871 & 2.290 & 2.554 & 3.762 & 3.604 & 0.960 & 3.875 & 3.831 \\
\hline $\mathrm{Cr}$ & 0.000 & 0.003 & 0.002 & 0.002 & 0.007 & 0.000 & 0.001 & 0.010 & 0.001 \\
\hline $\mathrm{Fe}^{3+}$ & & 0.122 & 0.684 & 0.434 & & & 0.001 & & \\
\hline $\mathrm{Fe}^{2+}$ & 2.446 & 0.000 & 0.000 & 0.000 & 2.999 & 2.395 & & 2.339 & 2.506 \\
\hline $\mathrm{Mg}$ & 7.075 & 0.000 & 0.000 & 0.000 & 6.468 & 6.622 & 0.000 & 7.094 & 6.999 \\
\hline $\mathrm{Mn}$ & 0.037 & 0.004 & 0.007 & 0.002 & 0.045 & 0.034 & 0.000 & 0.036 & 0.042 \\
\hline $\mathrm{Ca}$ & 0.022 & 1.950 & 1.982 & 1.955 & 0.032 & 0.056 & 0.011 & 0.026 & 0.017 \\
\hline $\mathrm{Na}$ & 0.000 & 0.000 & 0.000 & 0.000 & 0.000 & 0.026 & 1.004 & 0.010 & 0.000 \\
\hline K & 0.001 & 0.002 & 0.002 & 0.000 & 0.000 & 0.001 & 0.001 & 0.000 & 0.000 \\
\hline Total & 19.787 & 6.978 & 7.990 & 7.976 & 19.714 & 19.475 & 5.000 & 19.726 & 19.740 \\
\hline
\end{tabular}

Notes: All Fe as $\mathrm{FeO}$ in chlorite and chlorite/smectite and as $\mathrm{Fe}_{2} \mathrm{O}_{3}$ in prehnite, epidote, and albite.

terval logged in the hole (45-80 mbsf; see also MacLeod et al., 1995; Célérier et al., this volume). Chlorite-bearing veins constitute $>95 \%$ of the core data set, so conclusions based on this analysis are only applicable to this vein type.

The distributions of planar features in cores and logs correspond closely: both show similar distributions of dips (Fig. 15), with marked preferred orientations to the features and a maximum strike direction $\sim 12 \%-13 \%$ of total (Fig. 16A, B). This strongly implies that the same features are being compared. However, the maxima in vein density do not correspond because the FMS data are recorded relative to true north, whereas the core data are measured relative to the magnetization direction, which need not be north. The two data sets may be matched by rotation of the core data about a vertical axis such that the maximum densities of poles to planes are similar (Fig. $16 \mathrm{~B}, \mathrm{C})$. The result is qualitatively quite similar data sets which display a strong maximum in vein strikes in an east-west direction and a strong clustering of dips toward the south. We therefore conclude that chlorite-bearing veins are dominated by east-west strikes and moderate to steep southerly dips.

The inferred vertical-axis rotation raises two important issues. First, it implies that the stable magnetic remanence of the Hole $894 \mathrm{G}$ gabbros now points toward the north-northwest (MacLeod et al., 1995; Célérier et al., this volume). The disparity of orientations is too great to be explained by the secular variation in these slowly cooled rocks; it is more plausibly explained by tectonic rotation (MacLeod, Manning, et al., this volume). The core-log comparison suggests a vertical-axis component of rotation of either $\sim 30^{\circ}-40^{\circ}$ counterclockwise (if normal polarity; i.e., declination points to north) or $140^{\circ}-$ $150^{\circ}$ clockwise (if reversed polarity). The former is preferred in the absence of any other geological evidence for large rotations. Although previously thought to be of reversed polarity on the basis of their supposed 1 Ma age (Shipboard Scientific Party, 1993), a 30$40^{\circ}$ counterclockwise rotation requires that the gabbros of Site 894 are actually normally polarized.

The second issue is that the magnetic inclination data are also consistent with a horizontal-axis tectonic rotation, which implies tilting of the succession toward the north (assuming normal polarity) after vein formation. It is not possible to determine on the available evidence whether the vertical and horizontal components of rotation are part of a single rotation inclined about an inclined axis, or whether they result from multiple rotation episodes.

\section{DISCUSSION}

\section{Metamorphic Evolution of Hess Deep Gabbros} Early Metamorphism Associated with Amphibole Veins

Early metamorphism is summarized in Figure 17. Mineral assemblages and the high metamorphic temperatures implied by secondary clinopyroxene compositions require that the microfracturing now represented by microscopic amphibole veins began at $\sim 750^{\circ} \mathrm{C}$. As aqueous fluids penetrated these fractures, they reacted with the magmatic minerals in the gabbros to different degrees, but mineral assemblages are consistent with metamorphism predominantly in the amphibolite facies. Alteration associated with microscopic amphibole veins locally continued to lower grade (transitional greenschist-amphibolite facies) in coarse-grained rocks. Figure 17 schematically illustrates the variation in metamorphism with mineral identity near microscopic amphibole veins. Mafic minerals are strongly replaced by secondary mineral assemblages, whereas plagioclase replacement is limited. The mineral assemblage after magmatic clinopyroxene is calcic amphibole (actinolite to magnesio-hornblende), metamorphic clinopyroxene, and minute magnetite grains. Orthopyroxene and olivine are replaced by zoned patches of magnetite, talc, cummingtonite, and actinolite, although talc and magnetite are less common after orthopyroxene than olivine. This leads to metamorphic textures in which pristine magmatic plagioclase is preserved in a matrix of variably pseudomorphed mafic phases.

Macroscopic amphibole veins crosscut their microscopic counterparts, and mineral assemblages record lower amphibolite to transitional greenschist-amphibolite facies of metamorphism. Mineral as- 
semblages are distinct from those associated with microscopic amphibole veins in that calcic amphiboles may show evidence for a miscibility gap, magmatic plagioclase is locally altered to less calcic oligoclase to andesine and more calcic bytownite compositions, and secondary clinopyroxene is not observed (Fig. 17). Compositions of calcic amphiboles do not show strong dependence on adjoining mineral identity.

The most likely site for the deformation and metamorphism associated with both types of amphibole veins can be evaluated using the coupled thermal and mechanical models of fast-spreading oceanic crust by Phipps Morgan and Chen (1993). This model provides a simulated temperature-time history for lower crust in which heat is transported from asthenosphere and an axial magma chamber. It is appropriate for Hess Deep gabbros because they show no textural evidence (e.g., granoblastic hornfels) suggesting proximity to a later heat source such as an intrusion associated with Cocos-Nazca spreading. Although rare basaltic dikes thought to be related to Cocos-Nazca magmatism crosscut the gabbros (Shipboard Scientific Party, 1993; Allan et al., this volume), they are not sufficiently voluminous to have provided the thermal energy required for the pervasive amphibolite-facies metamorphism found at Site 894. In addition, the model assumes that advective heat transport by sea water occurred only below $600^{\circ} \mathrm{C}$. Although the earliest fluid-rock interaction occurred at $\sim 750^{\circ} \mathrm{C}$, it is likely that fluid fluxes were low at amphibolite-facies conditions (see below).

Figure 18 shows temperature-time relations for varying depth in the crust at a $50 \mathrm{~mm} / \mathrm{yr}$ half spreading rate, which is comparable to the spreading rates of $65 \mathrm{~mm} / \mathrm{yr}$ inferred for the EPR at the time of formation of Site 894 gabbros. It can be seen that gabbros at $2-3 \mathrm{~km}$ depth will experience $600^{\circ}-750^{\circ} \mathrm{C}$ temperatures $20,000-50,000 \mathrm{yr}$ after moving off the ridge axis. Applying these results to Site 894 gabbros indicates that temperatures in the gabbros would have decreased below $600^{\circ} \mathrm{C}$ within $1-3 \mathrm{~km}$ of the ridge axis. The model suggests that temperatures cool to below $500^{\circ} \mathrm{C}$ (transitional greenschist-amphibolite facies) $\sim 2-4 \mathrm{~km}$ from the axis. Thus, mineral assemblages associated with the microscopic and macroscopic amphibole veins require that early fracturing and metamorphism occurred very near the East Pacific Rise.

Macroscopic amphibole veins display no preferred orientation. Although we have not collected data on the orientations of microscopic amphibole veins, the rapid cooling experienced by gabbros at $2-3 \mathrm{~km}$ depth near the ridge axis suggests that the two amphibole vein types were separated by relatively short time intervals and are likely to have formed in broadly similar stress regimes. Assuming that the random orientations of the macroscopic amphibole veins characterize the microscopic amphibole veins as well, two mechanisms may be invoked to explain their origin: brittle deformation in the process zone of a normal fault; or thermal contraction in a stress regime in which differences in the magnitudes of principal stresses were small and variable. As noted by Agar (1994), a dense network of random cracks in oceanic gabbros could form in the region near the tip of a normal fault higher in the crust. Two factors suggest that this is probably not the origin for the amphibole veins: (1) the veins are not limited to a discrete horizon in the gabbros, but rather are found throughout the entire $\sim 150 \mathrm{~m}$ length of the core; and (2) the crosscutting relations between the two amphibole vein types and the range in temperatures recorded by the mineral assemblages strongly imply a prolonged history of fracture formation rather than a single failure event. The more probable origin for the microscopic and macroscopic amphibole veins is therefore high-temperature thermal contraction of the gabbros in a locally controlled and locally variable stress regime.

\section{Late Metamorphism Associated with Chlorite-bearing Veins}

Late metamorphism was principally associated with prominent, abundant chlorite-bearing veins found throughout Holes $894 \mathrm{~F}$ and

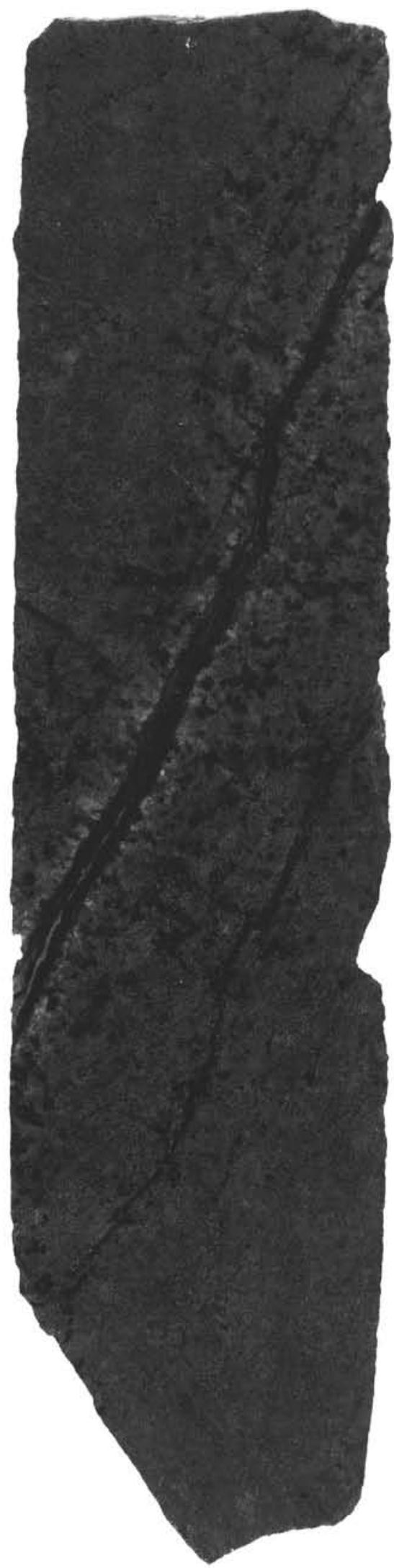

Figure 9. Chlorite-smectite veins in Sample 147-894G-9R-4, Piece 2, 6.5-30 $\mathrm{cm}$. Largest vein illustrates sporadic alteration of magmatic plagioclase to white secondary plagioclase and more extensive alteration of clinopyroxene to dark patches of intergrown chlorite and smectite up to $1 \mathrm{~cm}$ into wallrock. 
Table 8. Summary of inferred conditions of formation of vein types and associated alteration.

\begin{tabular}{llllll}
\hline \multicolumn{1}{c}{ Vein type: } & \multicolumn{1}{c}{ Microscopic amphibole } & $\begin{array}{c}\text { Macroscopic } \\
\text { amphibole }\end{array}$ & $\begin{array}{c}\text { Chlorite- } \\
\text { calcite-silicate }\end{array}$ & Chlorite-smectite & Zeolite-calcite \\
\hline Facies: & $\begin{array}{l}\text { Cpx amphibolite to amphibolite } \\
\text { (to g-a transition in coarse-grained gabbros) }\end{array}$ & $\begin{array}{c}\text { Amphibolite to } \\
\text { g-a transition }\end{array}$ & Greenschist & Subgreenschist & Zeolite \\
Temperature: & $\begin{array}{l}750^{\circ}-600^{\circ} \mathrm{C} \\
\left(750^{\circ}-450^{\circ} \mathrm{C}\right)\end{array}$ & $200^{\circ}-450^{\circ} \mathrm{C}$ & $250^{\circ}-450^{\circ} \mathrm{C}$ & $<250^{\circ} \mathrm{C}$ & $<150^{\circ} \mathrm{C}$ \\
References: & $1,2,3,4$ & $2,3,4$ & $4,5,6$ & 5 & 5,7 \\
\hline
\end{tabular}

Notes: $\mathrm{Cpx}=$ clinopyroxene, and $\mathrm{g}$-a transition $=$ greenschist-amphibolite transition. References are as follows: $1=$ pyroxene thermometry (this study), $2=$ Spear $(1981), 3=$ Liou et al. (1974), $4=$ Maruyama et al. (1983), $5=$ Cho et al. (1988), $6=$ Helgeson et al. (1978), and $7=$ Frey et al. (1991).

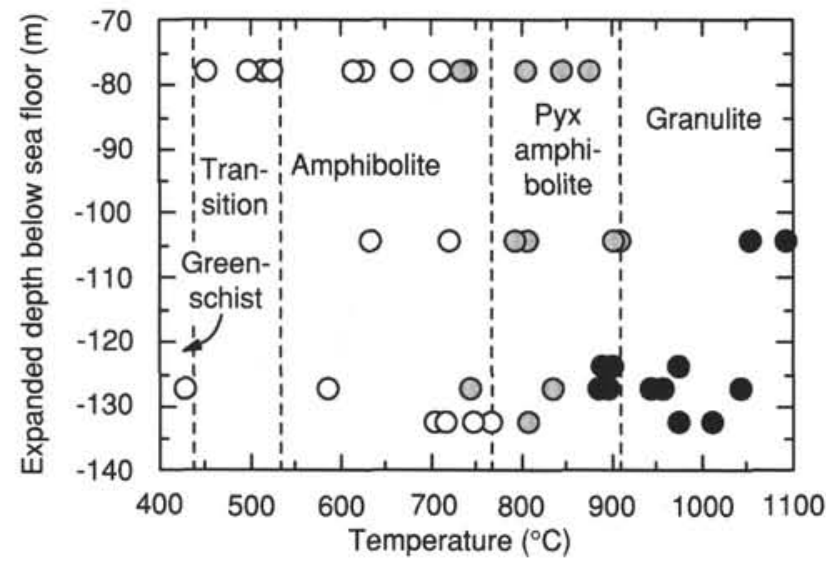

Rim, metamorphic
$\mathrm{cpx}$
Core, metamorphic
$\mathrm{cpx}$

Figure 10. Temperatures calculated from clinopyroxene compositions as a function of depth below seafloor using equations data of Anderson et al. (1993). Metamorphic facies from Liou et al. (1974) and Spear (1981). "Pyx amphibolite" refers to the amphibolite facies above clinopyroxene-in from Spear (1981). "Metamorphic cpx" refers to secondary clinopyroxene associated with microscopic amphibole veins.

894G (because of their low abundance, we do not discuss zeolitecalcite veins). Metamorphic mineral assemblages in chlorite-calcsilicate veins and associated wallrock alteration reflect greenschist facies conditions $\left(250^{\circ}-450^{\circ} \mathrm{C}\right)$, whereas those suggested by chlorite-smectite veins are subgreenschist facies $\left(<300^{\circ} \mathrm{C}\right)$. The low temperatures of chlorite-bearing veins are consistent with crosscutting relations which indicate that they formed later than amphibole veins.

Associated metamorphic mineral development is principally limited to zones within an average of $3 \mathrm{~mm}$ from these veins. As reported by Manning et al. (this volume), 1007 chlorite-bearing veins were observed in Holes $894 \mathrm{~F}$ and $894 \mathrm{G}$. When combined with $46.95 \mathrm{~m}$ of cored rocks from these holes, the maximum volume fraction of gabbros metamorphosed by chlorite-bearing veins is $6 \%$. This value is a maximum because it assumes complete alteration within the alteration halo about the veins. When compared to modal abundance of secondary minerals associated with amphibole veins ranging from 10 to $>50 \%$ (Shipboard Scientific Party, 1993), it is clear that despite the great abundance of these veins at Site 894 , their volumetric contribution to the metamorphism was small.

Chlorite-bearing veins display a strong preferred east-west orientation with moderate to steep southerly dips when reoriented based on magnetic and FMS results (Fig. 16). Because the East Pacific Rise strikes north-south at this latitude, their east-west orientations sug-

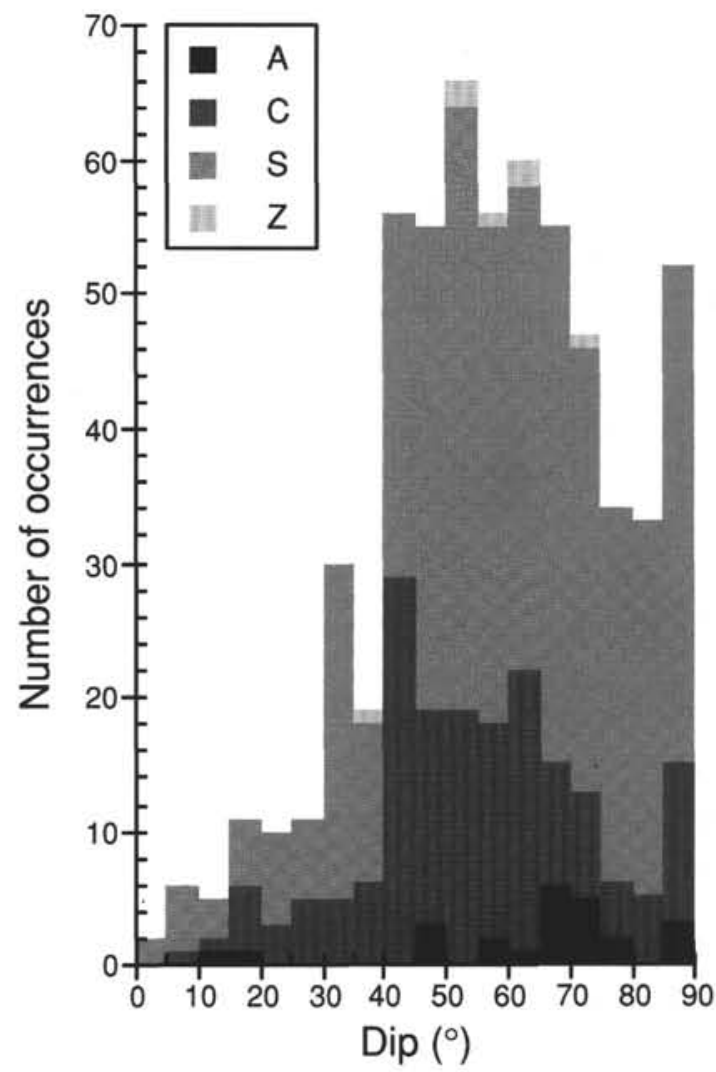

Figure 11. Histogram of vein dips relative to borehole axis. Vein types: $\mathrm{A}=$ macroscopic amphibole, $\mathrm{C}=$ chlorite-calc-silicate, $\mathrm{S}=$ chlorite-smectite, and $\mathrm{Z}=$ zeolite-calcite

gest formation by a mechanism unrelated to fracturing in an EPR hydrothermal system. East-west vein orientations are instead compatible with those expected for formation during east-west rifting as the Cocos Nazca Spreading Center propagated westward toward the East Pacific Rise. The timing and location of this metamorphism are more difficult to constrain than for higher temperature alteration because the rate of cooling of the lower crust slows dramatically below $500^{\circ} \mathrm{C}$. For example, for simulation conditions appropriate for Hess Deep Gabbros, the thermal models of Henstock et al. (1993) predict that temperatures at $2-3 \mathrm{~km}$ depth remain at $200^{\circ}-300^{\circ} \mathrm{C}$ from $2 \mathrm{~km}$ to well beyond $10 \mathrm{~km}$ from the ridge axis. Thus, although crosscutting relations and mineral assemblages clearly demonstrate that metamorphism related to chlorite-bearing veins postdates that related to amphibole veins, comparison to numerically simulated thermal histories provides only broad constraints on later vein formation of from two to tens of kilometers from the EPR axis, from 40,000 to several hundred thousand years after gabbro emplacement. 


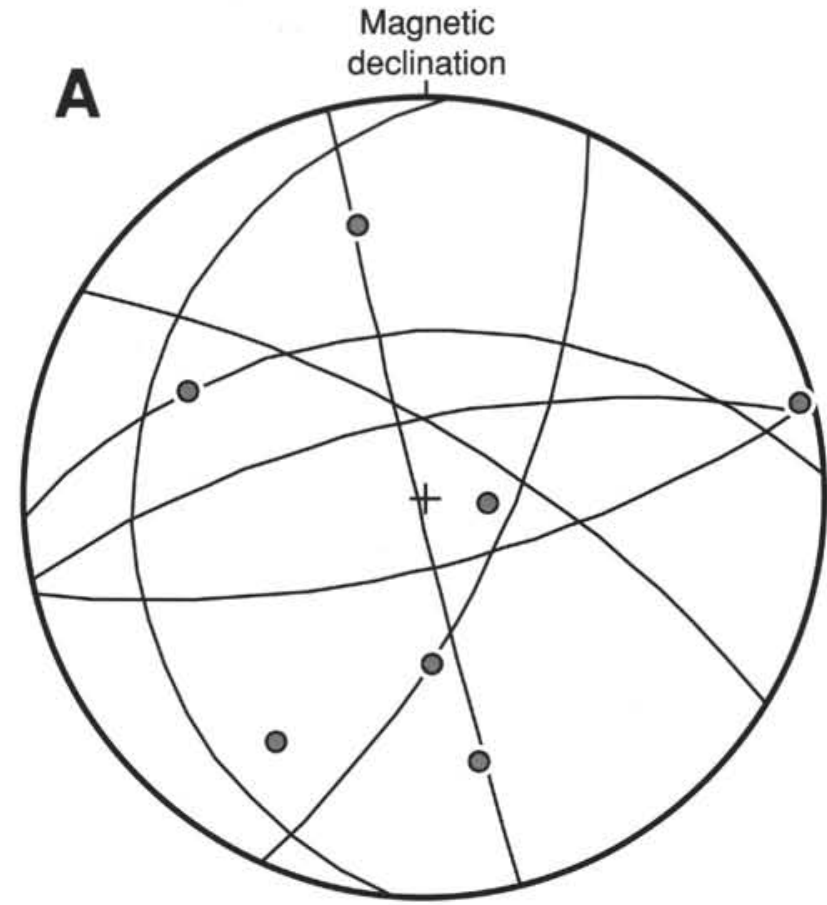

Restored to a common declination

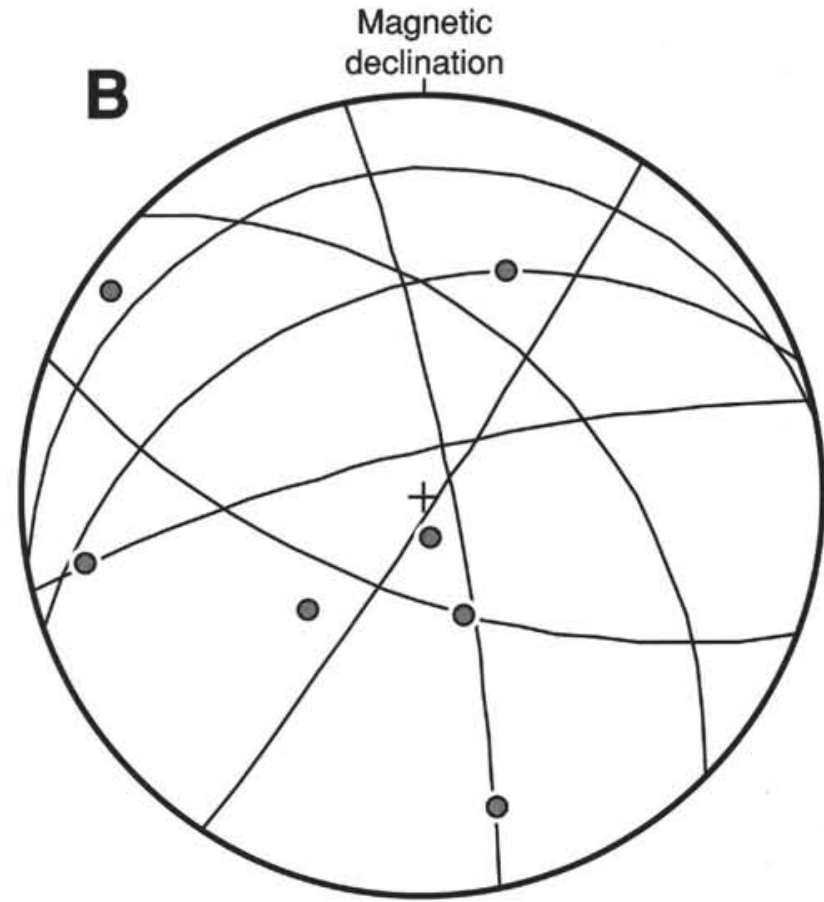

Restored to a common declination and inclination

Figure 12. Equal-area lower hemisphere projections showing orientations of seven macroscopic amphibole veins from Hole 894G restored to a common magnetic declination (A) and a common magnetic declination and inclination (B).

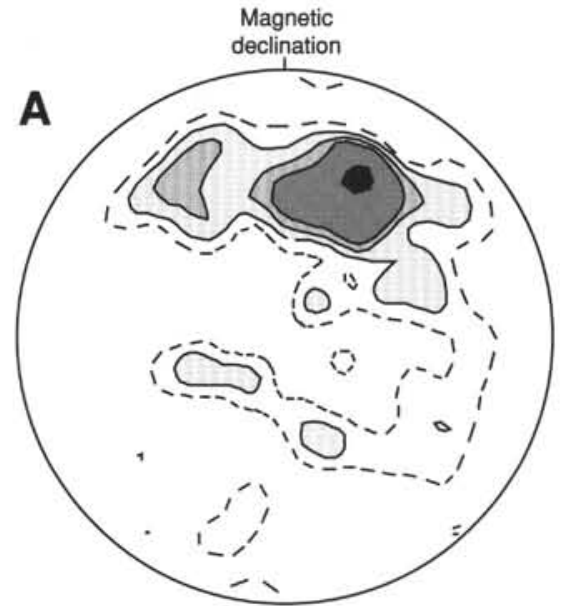

CHLORITE-CALC-SILICATE VEINS

Restored to a common declination

Max density $=9.4 \%$; contours $=1,2,3,4,8 \% ; N=84$

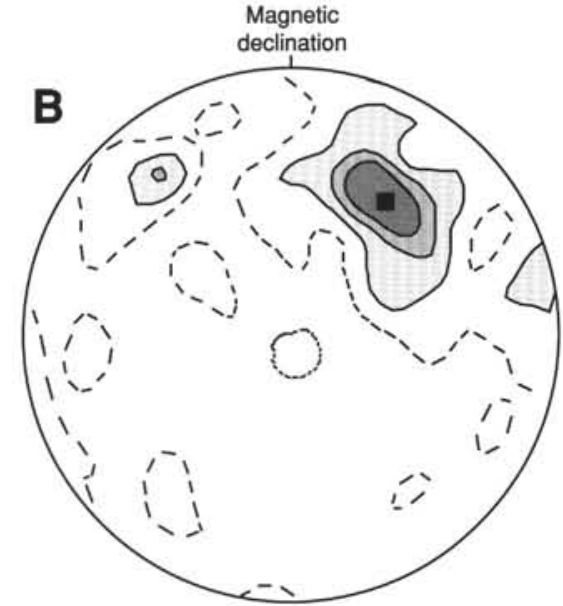

CHLORITE-SMECTITE VEINS

Restored to a common declination

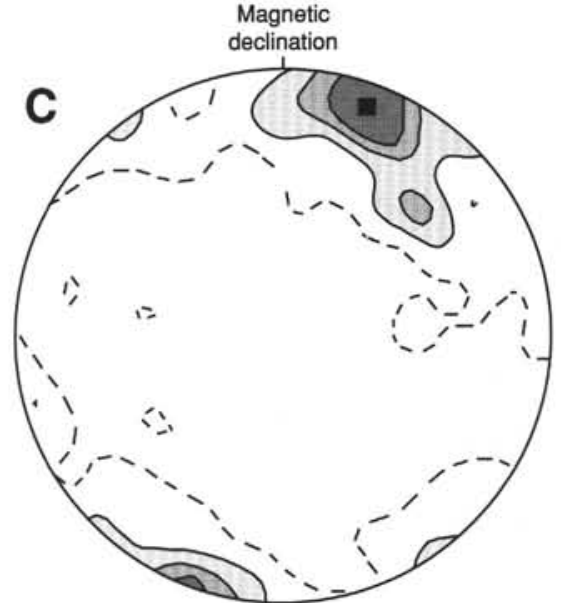

ALL CHLORITE VEINS

Restored to a common declination and inclination

Max density $=6.6 \%$; contours $=1,2,3,4 \% ; N=291$

Figure 13. A-C. Equal-area lower hemisphere projections showing contoured orientations of chlorite-bearing veins from Hole 894G.

\section{Constraints on the Thermal and Hydrologic Evolution of Hydrothermal Systems at Fast-spreading Centers} Implications for the Inception of Fracturing

The presence of metamorphic mineral assemblages formed at $600^{\circ}-750^{\circ} \mathrm{C}$ associated with microscopic amphibole veins requires the onset of brittle failure by microfracturing at high temperatures. Although these temperatures are greater than has previously been en- visioned for this setting (cf. Lister, 1974; Mével and Cannat, 1991), our observations are entirely consistent with the inferred seismic brittle-ductile transition of $\sim 750^{\circ} \mathrm{C}$ in the oceanic crust (Wiens and Stein, 1983; Bergman and Solomon, 1984). Maximum depths of earthquake foci decrease with increasing spreading rate (Huang and Solomon, 1988). These maximum depths correlate well with the $750^{\circ} \mathrm{C}$ isotherm along the ridge axis for varying spreading rates (Phipps Morgan and Chen, 1993). Thus, the presence of high-temperature meta- 


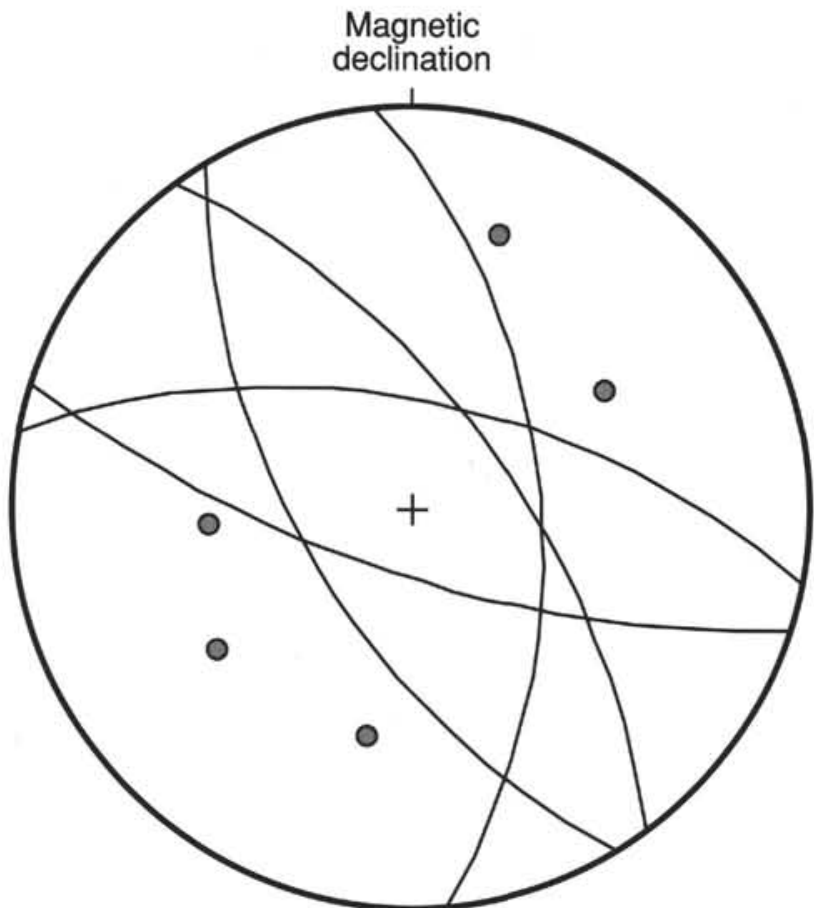

\section{ZEOLITE-CALCITE VEINS Restored to a common declination}

Figure 14. Equal-area lower hemisphere projections showing orientations of five zeolite-calcite veins from Hole 894G.

morphic mineral assemblages associated with a microfracture network at Site 894 represents geologic confirmation for the onset of brittle deformation at high-temperatures as inferred from seismic and numerical results.

The extent of gabbro alteration increases with the number of microscopic amphibole veins (Table 2). Modal analyses indicate that the total abundance of secondary minerals varies widely in Hole $894 \mathrm{G}$ and shows no distinct change with depth (Shipboard Scientific Party, 1993). Taking the extent of gabbro alteration as a guide to the abundance of microscopic amphibole veins, it can be concluded that the microfracture network did not develop homogeneously in space; rather, microfracture abundances were quite variable with depth. Moreover, the disparate temperatures recorded by the analyzed secondary clinopyroxenes (Fig. 10) imply that the microfracture network did not necessarily develop at the same time in the gabbros. Thus, microfracture formation and filling was probably spatially and temporally variable throughout the gabbros of Site 894. Previous models for the initial brittle failure of the ocean crust have postulated permeability generation at a downward propagating, isothermal cracking front (e.g., Lister, 1974). While this macroscopic view is adequate on a gross crustal scale, our results from Site 894 show that the inception of brittle failure by microfracturing is strongly heterogeneous on the scale of hundreds of meters.

\section{Implications for the Pore Network}

Our results also give a simple insight into how the pore network evolves with time during gabbro alteration at fast-spreading centers. The earliest fracturing is universally recorded as microscopic amphibole veins. Intersections among these veins are abundant, implying that the early pore network had high connectivity. Macroscopic
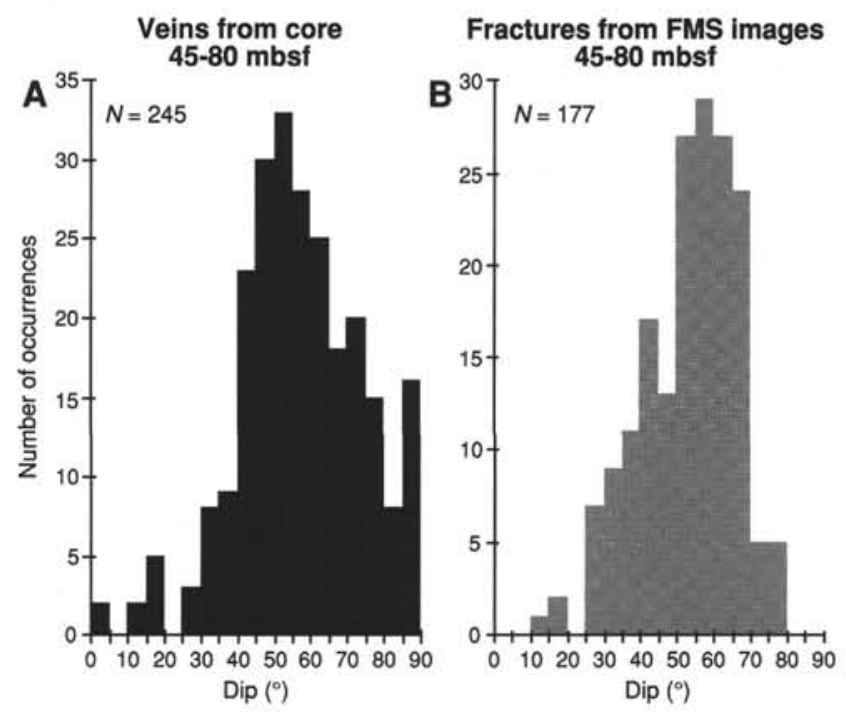

Figure 15. Comparison of vein dips from 45 to $80 \mathrm{~m}$ below seafloor from core (A) and FMS data (B) in Hole 894G. Vein dips from core corrected to a common magnetic declination.

amphibole veins in every case crosscut microscopic features, consistent with the mineral assemblages suggesting higher metamorphic grades associated with the microscopic amphibole veins. However, the later amphibole veins are substantially less abundant than their earlier counterparts. These observations show that the pore network evolved from a pervasive microscopic system to a more isolated, channeled macroscopic system as temperatures declined. Because earlier microfractures were more widely distributed, they allowed more extensive high-temperature alteration; fluid fluxes may have been substantially higher through the later macroscopic amphibole veins, but their more isolated distribution prevented them from having a significant mineralogical or chemical effect.

Unless facilitated by appropriate conditions later in the system's history, such as interaction with a new rift system, relatively little fracturing by thermal contraction or transport from the ridge axis probably occurs in EPR gabbros at or below temperatures of the greenschist facies. The late tectonic disruption unique to Hess Deep generated a second macroscopic fracture network superimposed on the pore network associated with cooling at the ridge. These fractures were filled by the chlorite-bearing and zeolite-calcite vein assemblages. Although substantially more abundant than the macroscopic amphibole veins, these later veins also represent discrete channels for the flow of fluid which limit fluid-rock reactions to the immediate wall-rock near the vein margins. As such, the late pore network associated with Hess Deep formation was also highly channeled. The change from a pore network originating via high-temperature thermal contraction of the gabbros themselves to a pore network generated by a later, superimposed stress regime is in fact a common feature in cooling intrusive rocks (e.g., Bird et al., 1988).

\section{Implications for Heat and Mass Transfer}

Although we present evidence for early high-temperature brittle failure of high-level gabbros from Site 894, it is important to emphasize that this does not necessarily imply large mass fluxes or strong advective heat transport by fluids migrating through the microfracture network. In fact, our observations suggest that high-temperature permeability generation had a comparatively minor effect on the thermal and chemical evolution of the gabbros. The compositions of amphiboles within microscopic amphibole veins vary as a function of 

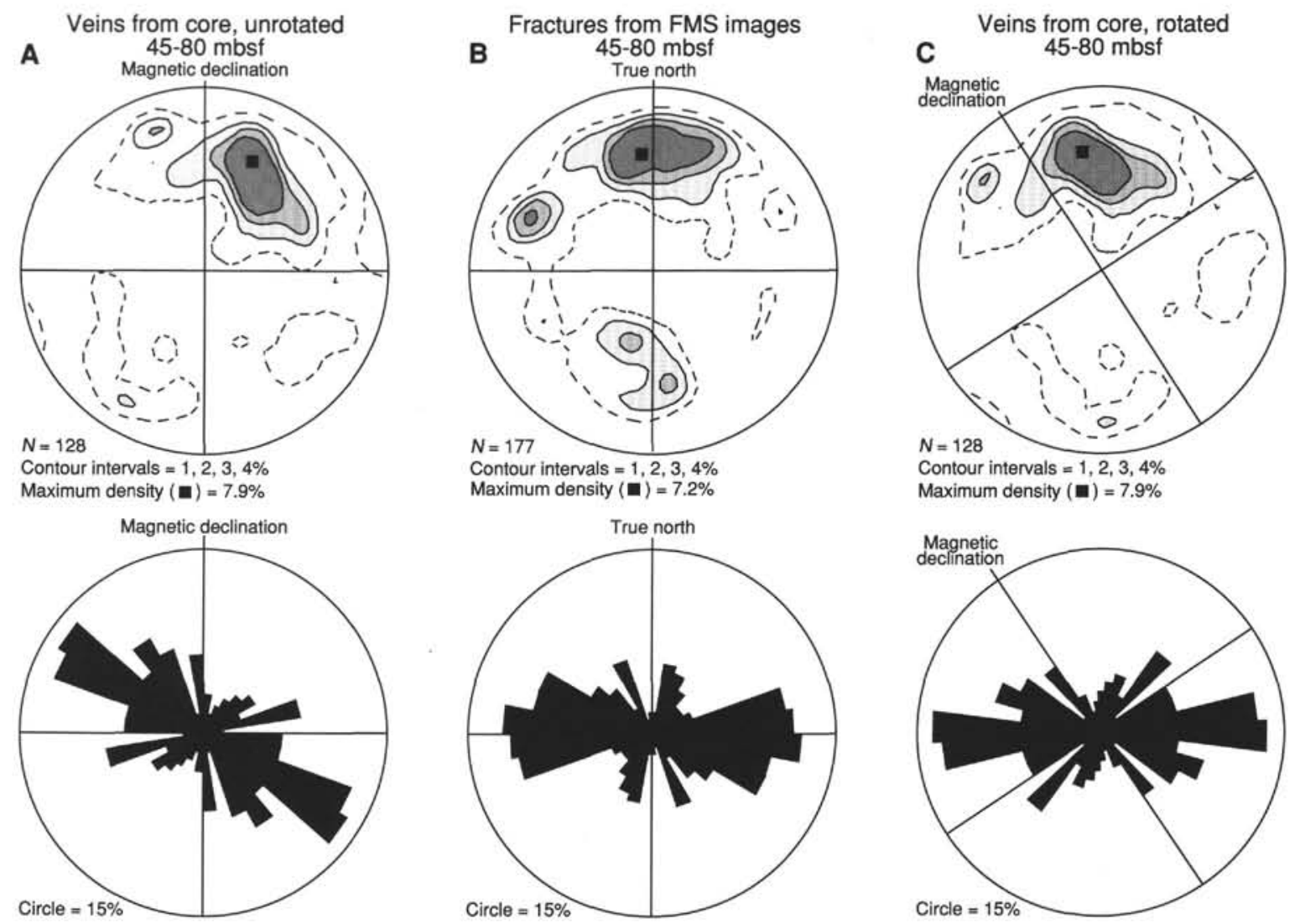

Figure 16. A-C. Comparison of contoured vein orientations (lower hemisphere equal-area projections) and rose diagrams of strikes from core and FMS data, 45-80 m below seafloor, Hole 894G. Data from core are restored to a common magnetic declination.

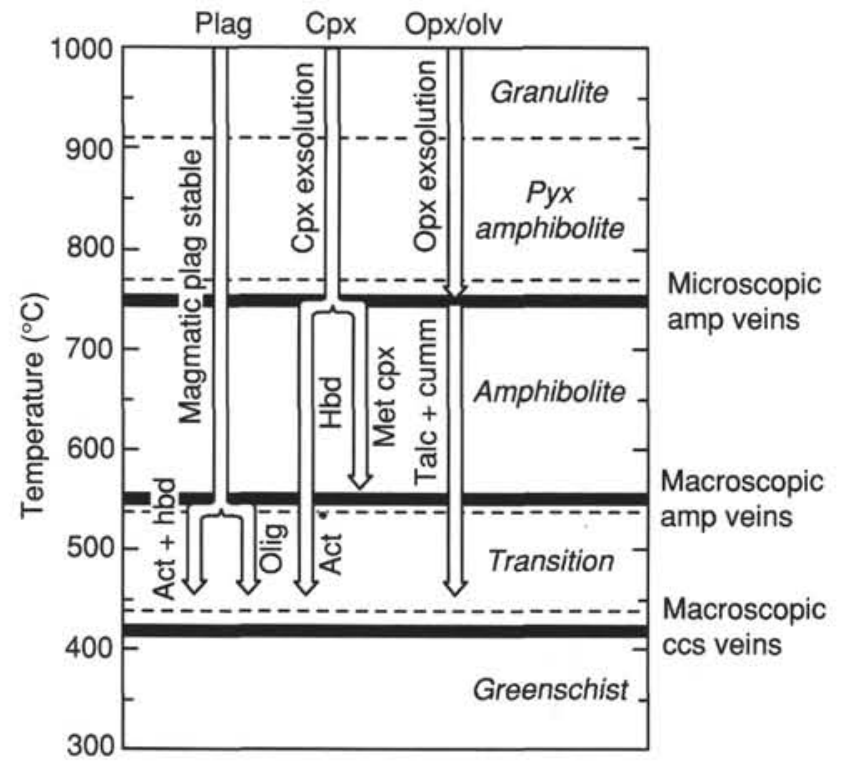

Figure 17. Schematic illustration of the evolution of fracture-controlled metamorphism with temperature at Site 894. Dashed horizontal lines show facies boundaries (see Fig. 10). Bold horizontal lines denote the inception of fracturing events. Vertical arrows show subsolidus history of principal magmatic phases in the gabbros. Plag = plagioclase, Olig = oligoclase, $\mathrm{Cpx}=$ clinopyroxene: $\mathrm{Opx}=$ orthopyroxene, $\mathrm{Pyx}=$ pyroxene, olv $=$ olivine, $\mathrm{Act}=$ actinolite, $\mathrm{Hbd}=$ hornblende, $\mathrm{Cumm}=$ cummingtonite, $\mathrm{Met}=$ metamorphic, amp $=$ amphibole, and ccs $=$ chlorite-calc-silicate.

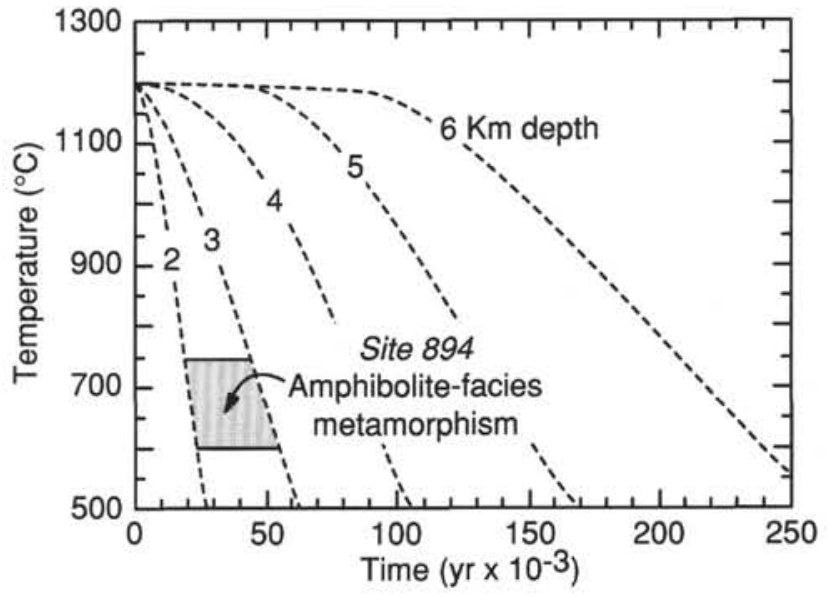

Figure 18. Timing of formation of amphibolite-facies metamorphism in Site 894 gabbros. Dashed lines show temperature-time paths at different depths in oceanic gabbros for a $50 \mathrm{~mm} / \mathrm{yr}$ spreading rate (Phipps Morgan and Chen, 1993). 
the adjacent mineral grains: where in contact only with Al-rich plagioclase, the amphiboles are more aluminous; where in contact with only $\mathrm{Al}$-poor mafic phases, the amphiboles are correspondingly less aluminous; and where adjoined by both plagioclases and a mafic phase, the amphiboles have intermediate $\mathrm{Al}$ contents. These observations demonstrate that length scales for material transport were low during formation of microscopic amphibole veins. Low transport length scales, coupled with the high temperatures of fracture formation, imply that fluid fluxes through these fractures were low and that reaction rates were rapid. Thus, when local zones failed by microfracturing in the heterogeneously deforming gabbro section, metamorphic mineral assemblages associated with microscopic amphibole veins probably precipitated so quickly that individual portions of the pore network only contributed to the entire system's permeability for a short time. These observations imply that the onset of enhanced gabbro cooling associated with large fluid fluxes does not coincide with the onset of fracturing, a conclusion important for the conceptual models that underlie numerical simulations of the thermal, mechanical, and chemical histories of the oceanic crust near ridge axes (e.g., Phipps Morgan et al., 1987; Brikowski and Norton, 1989; Henstock et al., 1993; Phipps Morgan and Chen, 1993).

\section{Constraints on Comparisons of the Hydrothermal Roots of Fast- and Slow-spreading Centers}

Mével and Cannat (1991) proposed that gabbro metamorphism at fast-spreading rates should follow the downward propagation of a $500^{\circ} \mathrm{C}$ cracking front. In their model, permeability is generated entirely by brittle fracturing; the absence of high-temperature ductile shear zones in this setting prevents gabbro interaction with sea water at temperatures above $500^{\circ} \mathrm{C}$. In contrast, high-temperature ductile shear zones cut gabbros formed at slow-spreading ridges and are usually associated with amphibolite- to granulite-facies metamorphic mineral assemblages. Mével and Cannat (1991) suggested that the ductile shear zones provide the permeable conduits for high-temperature metamorphic hydration reactions. As the gabbros cool, later brittle failure at $\sim 500^{\circ} \mathrm{C}$ leads to further hydration reactions which overprint the high-temperature assemblages associated with the shear zones.

Because the Site 894 gabbros are the first stratigraphically continuous plutonic section from a demonstrably fast-spreading center, they provide a unique test of the model proposed by Mével and Cannat (1991). The vein-controlled metamorphism of Site 894 gabbros is entirely a brittle phenomenon. No evidence for the plastic deformation common in gabbros from slow-spreading ridges was observed. This suggests that the model adequately explains the style of deformation at Site 894. However, the temperatures required to explain the mineral assemblages and compositions associated with the microscopic amphibole veins are $100^{\circ}-250^{\circ} \mathrm{C}$ higher than the model predicts. It is also important to note that local variations in the rate and distribution of strain may complicate Mével and Cannat's conceptual framework, leading to significant lateral and vertical variations in the extent and style of deformation. For example, our observations suggest heterogeneous development of the pore network in time. Also, the metamorphosed gabbros from Site 894 represent only a small fraction of the plutonic section exposed at Hess Deep, and textural and geochemical evidence indicate that Holes $894 \mathrm{~F}$ and $894 \mathrm{G}$ penetrated rocks from high levels in the gabbro sequence which appear to have crystallized near the axial magma chamber. Strain-rate variations near the magma chamber may result in localized brittle deformation and fluid-rock interaction, such as is found in the Site 894 gabbros, whereas gabbros from lower in the crust or several kilometers away laterally may show less high-temperature metamorphism. This conclusion is consistent with preliminary petrographic observations of gabbros from elsewhere in Hess Deep (Francheteau et al., 1990; Hekinian, 1993; Gillis et al., 1993a) as well as from the lower plutonic section of the Oman ophiolite (e.g., Nehlig and Juteau, 1988; Stakes and Taylor, 1992).

In summary, metamorphosed gabbros from Site 894 display no evidence for the ductile deformation prevalent at slow-spreading centers, compatible with the predictions of Mével and Cannat (1991). However, the $600^{\circ}-750^{\circ} \mathrm{C}$ temperatures inferred for metamorphism associated with the earliest microscopic amphibole veins implies that the onset of fracturing by brittle failure occurs at higher temperatures than inferred from mechanical models (e.g., Lister, 1974). The high degree of gabbro replacement by secondary minerals at Site 894 may result from the fortuitous siting of Holes $894 \mathrm{~F}$ and $894 \mathrm{G}$ in gabbros crystallized near the axial magma chamber, where the extent of fracturing could be greater than deeper in the plutonic section.

\section{ACKNOWLEDGMENTS}

We thank S. Agar and D. Bideau for insightful reviews of the manuscript, and G. Früh-Green, K. Gillis, D. Kelley, C. Lécuyer, C. Mével and other members of the scientific party for shipboard and post-cruise discussions.

\section{REFERENCES}

Agar, S.M., 1990. Fracture evolution in the upper ocean crust: evidence from DSDP Hole 504B. In Knipe, R.J., and Rutter, E.H. (Eds.), Deformation Mechanisms, Rheology and Tectonics. Geol. Soc. Spec. Publ. London, 54:41-50.

1994. Rheological evolution of the ocean crust: a microstructural view. J. Geophys. Res., 99:3175-3200.

Anderson, D.J., Lindsley, D.H., and Davidson, P.M., 1993. QUILF: a PAS$\mathrm{CAL}$ program to assess equilibria among $\mathrm{Fe}-\mathrm{Mg}-\mathrm{Ti}$ oxides, pyroxenes, olivine and quartz. Comput. Geosci., 19:1333-1350.

Batiza, R., and Vanko, D.A., 1985. Petrologic evolution of large failed rifts in the eastern Pacific: petrology of volcanic and plutonic rocks from the Mathematician Ridge area and the Guadalupe Trough. J. Petrol., 26:564-602.

Bayliss, P., 1975. Nomenclature of the trioctahedral chlorites. Can. Mineral., $13: 178-180$.

Bergman, E.A., and Solomon, S.C., 1984. Source mechanisms of earthquakes near mid-ocean ridges from body waveform inversion: implications for the early evolution of oceanic lithosphere. J. Geophys. Res., $89: 11415-11441$

Bettison, L.A., and Schiffman, P., 1988. Compositional and structural variations of phyllosilicates from the Point Sal ophiolite, California. Am. Mineral., 73:62-76.

Bideau, D., Hebert, R., Hekinian, R., and Cannat, M., 1991. Metamorphism of deep-seated rocks from the Garret Ultrafast Transform (East Pacific Rise near $13^{\circ} 25^{\prime}$ S). J. Geophys. Res., 96:10079-10099.

Bird, D.K., Manning, C.E., and Rose, N.M., 1988. Hydrothermal alteration of Tertiary layered gabbros, East Greenland. Am. J. Sci., 288:405-457.

Bird, D.K., Rogers, D., and Manning, C.E., 1986. Mineralized fracture systems of the Skaergaard Intrusion, East Greenland. Medd. Groenl.: Geosci., 16:68.

Bonatti, E., Honnorez, J., Kirst, P., and Radicati, F., 1975. Metagabbros from the Mid-Atlantic Ridge at $6^{\circ} \mathrm{N}$ : contact-hydrothermal-dynamic metamorphism beneath the axial valley. J. Geol., 83:61-78.

Brikowski, T., and Norton, D., 1989. Influence of magma chamber geometry on hydrothermal activity at mid-ocean ridges. Earth Planet. Sci. Lett., 93:241-255.

Burnett, M.S., Caress, D.W., and Orcutt, J.A., 1989. Tomographic image of the magma chamber at $12^{\circ} 50^{\prime} \mathrm{N}$ on the East Pacific Rise. Nature, 339:206-208

Cann, J.R., Strens, M.R., and Rice, A., 1985. A simple magma-driven thermal balance model for the formation of volcanogenic massive sulphides. Earth Planet. Sci. Lett., 76:123-134.

Cannat, M., and Mével, C., 1991. Stretching of the deep crust at the slowspreading Southwest Indian Ridge. Tectonophysics, 190:73-94.

Cannat, M., Mével, C., and Stakes, D., 1991. Normal ductile shear zones at an oceanic spreading ridge: tectonic evolution of Site 735 gabbros (southwest Indian Ocean). In Von Herzen, R.P., Robinson, P.T., et al., 
Proc. ODP, Sci. Results, 118: College Station, TX (Ocean Drilling Program), 415-429.

Detrick, R.S., Buhl, P., Vera, E., Mutter, J., Orcutt, J., Madsen, J., and Brocher, T., 1987. Multi-channel seismic imaging of a crustal magma chamber along the East Pacific Rise. Nature, 326:35-41.

Detrick, R.S., Harding, A.J., Kent, G.M., Orcutt, J.A., Mutter, J.C., and Buhl, P., 1993. Seismic structure of the southern East Pacific Rise. Science, 259:499-503.

Dick, H.J.B., Meyer, P.S., Bloomer, S., Kirby, S., Stakes, D., and Mawer, C., 1991. Lithostratigraphic evolution of an in-situ section of oceanic Layer 3. In Von Herzen, R.P., Robinson, P.T., et al., Proc. ODP, Sci. Results, 118: College Station, TX (Ocean Drilling Program), 439-538.

Ekstrom, M.P., Dahan, C., Chen, M.-Y., Lloyd, P., and Rossi, D.J., 1987. Formation imaging with microelectrical scanning arrays. Log Analyst, 28:294-306.

Francheteau, J., Armijo, R., Cheminée, J.L., Hekinian, R., Lonsdale, P.F., and Blum, N., 1990. 1 Ma East Pacific Rise oceanic crust and uppermost mantle exposed by rifting in Hess Deep (equatorial Pacific Ocean). Earth Planet. Sci. Lett., 101:281-295.

Frey, M., de Capitani, C., and Liou, J.G., 1991. A new petrogenetic grid for low-grade metabasites. J. Metamorph. Geol., 9:497-509.

Gillis, K.M., and the Leg 147 Scientific Party, 1993a. Hydrothermal evolution of EPR lower crust exposed at Hess Deep. Eos, 74 (Suppl.):653. (Abstract)

Gillis, K.M., Thompson, G., and Kelley, D.S., 1993b. A view of the lower crustal component of hydrothermal systems at the Mid-Atlantic Ridge. $J$. Geophys. Res., 98:19597-19619.

Girardeau, J., and Francheteau, J., 1993. Plagioclase-wehrlites and peridotites on the East Pacific Rise (Hess Deep) and the Mid-Atlantic Ridge (DSDP Site 339): evidence for magma percolation in the oceanic upper mantle. Earth Planet. Sci. Lett., 115:137-149.

Gregory, R.T., and Taylor, H.P., Jr., 1981. An oxygen isotope profile in a section of Cretaceous oceanic crust, Samail ophiolite, Oman: evidence for $\delta^{18} \mathrm{O}$-buffering of the oceans by deep $(>5 \mathrm{~km})$ seawater-hydrothermal circulation at mid-ocean ridges. J. Geophys. Res., 86:2737-2755.

Harper, G.D., 1985. Tectonics of slow spreading mid-ocean ridges and consequences of a variable depth to the brittle/ductile transition. Tectonics, 4:395-409.

Hekinian, R., Bideau, D., Francheteau, J., Cheminee, J.L., Armijo, R., Lonsdale, P., and Blum, N., 1993. Petrology of the East Pacific Rise crust and upper mantle exposed in the Hess Deep (eastern equatorial Pacific). $J$. Geophys. Res., 98:8069-8094.

Helgeson, H.C., Delany, J.M., Nesbitt, H.W., and Bird, D.K., 1978. Summary and critique of the thermodynamic properties of rock-forming minerals. Am. J. Sci., 278A.

Helmstaedt, H., and Allen, J.M., 1977. Metagabbronorite from DSDP Hole 334: an example of high temperature deformation and recrystallization near the Mid-Atlantic ridge. Can. J. Earth Sci., 14:886-898.

Henstock, T.J., Woods, A.W., and White, R.S., 1993. The accretion of oceanic crust by episodic sill injection. J. Geophys. Res., 98:4143-4161.

Hey, R., Deffeyes, K.S., Johnson, G.L., and Lowrie, A., 1972. The Galapagos triple junction and plate motions in the East Pacific. Nature, 237:2022.

Honnorez, J., Mével, C., and Montigny, R., 1984. Geotectonic significance of gneissic amphibolites from the Vema fracture zone, equatorial MidAtlantic Ridge. J. Geophys. Res., 89:11379-11400.

Huang, P.Y., and Solomon, S.C., 1988. Centroid depths of mid-ocean ridge earthquakes: dependence on spreading rate. J. Geophys. Res., 93:1344513477.

Ito, E., and Anderson, A.T., Jr., 1983. Submarine metamorphism of gabbros from the Mid Cayman Rise: petrographic and mineralogic constraints on hydrothermal processes at slow-spreading ridges. Contrib. Mineral. Petrol., 82:371-388.

Johnson, G.L., Vogt, P.R., Hey, R., Campsie, J., and Lowrie, A., 1976. Morphology and structure of the Galapagos Rise. Mar. Geol., 21:81-120.

Karson, J.A., 1990. Seafloor spreading on the Mid-Atlantic Ridge: implications for the structure of ophiolites and oceanic lithosphere produced in slow-spreading environments. In Malpas, J., Moores, E.M., Panayiotou, A., and Xenophontos, C. (Eds.), Ophiolites: Oceanic Crustal Analogues: Proc. Symp. "Troodos 1987." Nicosia, Cyprus (Minist. Agric. Nat. Resour.), 547-555.

Karson, J.A., Thompson, G., Humphris, S.E., Edmond, J.M., Bryan, W.B., Brown, J.R., Winters, A.T., Pockalny, R.A., Casey, J.F., Campbell, A.C., Klinkhammer, G., Palmer, M.R., Kinzler, R.J., and Sulanowska, M.M.,
1987. Along-axis variations in seafloor spreading in the MARK area. Nature, 328:681-685.

Kashintsev, G.L., Kuz'min, M.I., and Popolitov, E.N., 1982. Composition and structure of the oceanic crust in the vicinity of the Hess Basin (Pacific Ocean). Geotectonics, 16:512-520.

Kelley, D.S., Gillis, K.M., and Thompson, G., 1993. Fluid evolution in submarine magma-hydrothermal systems at the Mid-Atlantic Ridge. J. Geophys. Res., 98:19579-19596.

Kent, G.M., Harding, A.J., and Orcutt, J.A., 1990. Evidence for a smaller magma chamber beneath the East Pacific Rise at $9^{\circ} 30$ N. Nature, $344: 650-653$.

Leake, B.E., 1978. Nomenclature of amphiboles. Can. Mineral., 16:501520.

Lindsley, D.H., 1983. Pyroxene thermometry. Am. Mineral., 68:477-493.

Liou, J.G., Kuniyoshi, S., and Ito, K., 1974. Experimental studies of the phase relations between greenschist and amphibolite in a basaltic system. Am. J. Sci., 274:613-632.

Liou, J.G., Maruyama, S., and Cho, M., 1985. Phase equilibria and mineral parageneses of metabasites in low-grade metamorphism. Mineral. Mag., 49:321-333.

Lippard, S.J., Shelton, A.W., and Gass, I.G., 1986. The Ophiolite of Northern Oman. Geol. Soc. London Mem., 11.

Lister, C.R.B., 1974. On the penetration of water into hot rock. Geophys. J. R. Astron. Soc., 39:465-509.

1983. The basic physics of water penetration into hot rock. In Rona, P.A., Boström, K., Laubier, L., and Smith, K.L., Jr. (Eds.), Hydrothermal Processes at Seafloor Spreading Centers: New York (Plenum), 141-168.

Lonsdale, P., 1988. Structural pattern of the Galapagos microplate and evolution of the Galapagos triple junction. J. Geophys. Res., 93:13551-13574.

Lowell, R.P., 1975. Circulation in fractures, hot springs, and convective heat transport on mid-ocean ridge crests. Geophys. J. R. Astron. Soc., 40:351365.

Lowell, R.P., and Burnell, D.K., 1991. A numerical model for magmahydrothermal boundary layer heat transfer in the oceanic crust. Earth Planet. Sci. Lett., 104:56-69.

Lowell, R.P., and Germanovich, L.N., 1994. On the temporal evolution of high-temperature hydrothermal systems at ocean ridge crests. J. Geophys. Res., 99:565-575.

MacLeod, C.J., Célérier, B., and Harvey, P.K., 1995. Further techniques for core reorientation by core-log integration: application to structural studies of the lower oceanic crust in Hess Deep, eastern Pacific. Sci. Drilling, 5:77-86.

MacLeod, C.J., Parson, L.M., and Sager, W.W., 1994. Reorientation of cores using the Formation MicroScanner and Borehole Televiewer: application to structural and paleomagnetic studies with the Ocean Drilling Program. In Hawkins, J., Parson, L., Allan, J., et al., Proc. ODP, Sci. Results, 135: College Station, TX (Ocean Drilling Program), 301-311.

MacLeod, C.J., Parson, L.M., Sager, W.W., and the ODP Leg 135 Scientific Party, 1992. Identification of tectonic rotations in boreholes by the integration of core information with Formation MicroScanner and Borehole Televiewer images. In Hurst, A., Griffiths, C.M., and Worthington, P.F. (Eds.), Geological Applications of Wireline Logs II. Geol. Soc. Spec. Publ. London, 65:235-246.

Manning, C.E., and Bird, D.K., 1986. Hydrothermal clinopyroxenes of the Skaergaard intrusion. Contrib. Mineral. Petrol., 92:437-447.

Maruyama, S., Suzuki, K., and Liou, J.G., 1983. Greenschist-amphibolite transition equilibria at low pressures. J. Petrol., 24:583-604.

Mével, C., 1987. Evolution of oceanic gabbros from DSDP Leg 82: influence of the fluid phase on metamorphic crystallizations. Earth Planet. Sci. Lett., 83:67-79.

1988. Metamorphism of oceanic layer 3, Gorringe Bank, eastern Atlantic. Contrib. Mineral. Petrol., 100:496-509.

Mével, C., Caby, R., and Kienast, J.R., 1978. Amphibolite facies conditions in the oceanic crust: example of amphibolitized flaser-gabbro and amphibolites from the Chenaillet ophiolite massif (Haute Alpes, France). Earth Planet. Sci. Lett., 39:98-108.

Mével, C., and Cannat, M., 1991. Lithospheric stretching and hydrothermal processes in oceanic gabbros from slow-spreading ridges. In Peters, T., Nicolas, A., and Coleman, R.G. (Eds.), Ophiolite Genesis and Evolution of the Oceanic Lithosphere: Dordrecht (Kluwer), 293-312.

Nehlig, P., 1993. Interactions between magma chambers and hydrothermal systems: oceanic and ophiolitic constraints. J. Geophys. Res., 98:1962119633. 
, 1994. Fracture and permeability analysis in magma-hydrotherma transition zones in the Samail ophiolite (Oman). J. Geophys. Res., 99:589-601.

Nehlig, P., and Juteau, T., 1988. Flow porosities, permeabilities and preliminary data on fluid inclusions and fossil thermal gradients in the crustal sequence of the Sumail ophiolite (Oman). Tectonophysics, 151:199-221

Newmark, R.L., Anderson, R.N., Moos, D., and Zoback. M.D., 1985. Sonic and ultrasonic logging of Hole 504B and its implications for the structure, porosity, and stress regime of the upper $1 \mathrm{~km}$ of the oceanic crust. In Anderson, R.N., Honnorez, J., Becker, K., et al., Init. Repts. DSDP, 83 Washington (U.S. Govt. Printing Office), 479-510.

Nicolas, A., 1989. Structure of Ophiolites and Dynamics of the Oceanic Lithosphere: Boston (Kluwer).

Papike, J.J., Cameron, K.L., and Baldwin, K., 1974. Amphiboles and pyroxenes: characterization of other than quadrilateral components and estimates of ferric iron from microprobe data. Geol. Soc. Am. Abstr. Progr., 6:1053-1054. (Abstract)

Phipps Morgan, J., and Chen, Y.J., 1993. The genesis of oceanic crust: magma injection, hydrothermal circulation, and crustal flow. J. Geophys. Res., 98:6283-6297.

Phipps Morgan, J., Parmentier, E.M., and Lin, J., 1987. Mechanisms for the origin of mid-ocean ridge axial topography: implications for the thermal and mechanical structure at accreting plate boundaries. J. Geophys. Res., 92:12823-12836.

Prichard, H.M., and Cann, J.R., 1982. Petrology and mineralogy of dredged gabbro from Gettysburg Bank, Eastern Atlantic. Contrib. Mineral. Petrol., 79:46-55.

Robinson, P., Spear, F.S., Schumacher, J.C., Laird, J., Klein, C., Evans, B.W., and Doolan, B.L., 1982. Phase relations of metamorphic amphiboles: natural occurrence and theory. In Veblen, D.R., and Ribbe, P.H (Eds.), Amphiboles: Petrology and Experimental Phase Relations. Rev. Mineral., 9B:1-211.

Rona, P.A., 1988. Hydrothermal mineralization at oceanic ridges. Can. Mineral., 26:431-465.

Searle, R.C., and Francheteau, J., 1986. Morphology and tectonics of the Galapagos triple junction. Mar. Geophys. Res., 8:95-129.

Shipboard Scientific Party, 1992. Site 504. In Dick, H.J.B., Erzinger, J. Stokking, L.B., et al., Proc. ODP, Init. Repts., 140: College Station, TX (Ocean Drilling Program), 37-200.

1993. Site 894. In Gillis, K., Mével, C., Allan, J., et al., Proc. ODP, Init. Repts., 147: College Station, TX (Ocean Drilling Program), 45-108.

Sinton, J.M., and Detrick, R.S., 1992. Mid-ocean ridge magma chambers. J. Geophys. Res., 97:197-216.
Spear, F.S., 1981. An experimental study of hornblende stability and compositional variability in amphibolite. Am. J. Sci., 281:697-734.

Stakes, D., Mével, C., Cannat, M., and Chaput, T., 1991. Metamorphic stratigraphy of Hole 735B. In Von Herzen, R.P., Robinson, P.T., et al., Proc. ODP, Sci. Results, 118: College Station, TX (Ocean Drilling Program), 153-180.

Stakes, D.S., and Taylor, H.P., Jr., 1992. The northern Samail Ophiolite: an oxygen isotope, microprobe, and field study. J. Geophys. Res., 97:70437080 .

Stakes, D.S., Taylor, H.P., Jr., and Fisher, R.L., 1983. Oxygen-isotope and geochemical characterization of hydrothermal alteration in ophiolite complexes and modern oceanic crust. In Gass, I.G., Lippard, S.J., and Shelton, A.W. (Eds.), Ophiolites and Oceanic Lithosphere: London (Blackwell), 199-204.

Stakes, D.S., and Vanko, D.A., 1986. Multistage hydrothermal alteration of gabbroic rocks from the failed Mathematician Ridge. Earth Planet. Sci. Lett., 79:75-92.

Strens, M.R, and Cann, J.R., 1982. A model of hydrothermal circulation in fault zones at mid-ocean ridge crests. Geophys. J. R. Astron. Soc., $71: 225-240$.

1986. A fracture-loop thermal balance model of black smoker circulation. Tectonophysics, 122:307-324.

Terzaghi, R.D., 1965. Sources of error in joint surveys. Geotechnique, 15:287-304.

Toomey, D.R., Purdy, G.M., Solomon, S.C., and Wilcock, W.S.D., 1990. The three-dimensional seismic velocity structure of the East Pacific Rise near latitude $9^{\circ} 30 `$ N. Nature, 347:639-645.

Vera, E.E., Mutter, J.C., Buhl, P., Orcutt, J.A., Harding, A.J., Kappus, M.E., Detrick, R.S., and Brocher, T.M., 1990. The structure of 0- to 0.2-m.y.old oceanic crust at $9^{\circ} \mathrm{N}$ on the East Pacific Rise from expanded spread profiles. J. Geophys. Res., 95:15529-15556.

Wiens, D.A., and Stein, S., 1983. Age dependence of oceanic intraplate seismicity and implications for lithospheric evolution. J. Geophys. Res., $88: 6455-6468$

Wilcock, W.S.D., Solomon, S.C., Purdy, G.M., and Toomey, D.R., 1992. The seismic attenuation structure of a fast-spreading mid-ocean ridge. Science, 258:1470-1474

Date of initial receipt: 2 August 1994

Date of acceptance: 24 February 1995 Ms 147SR-011 


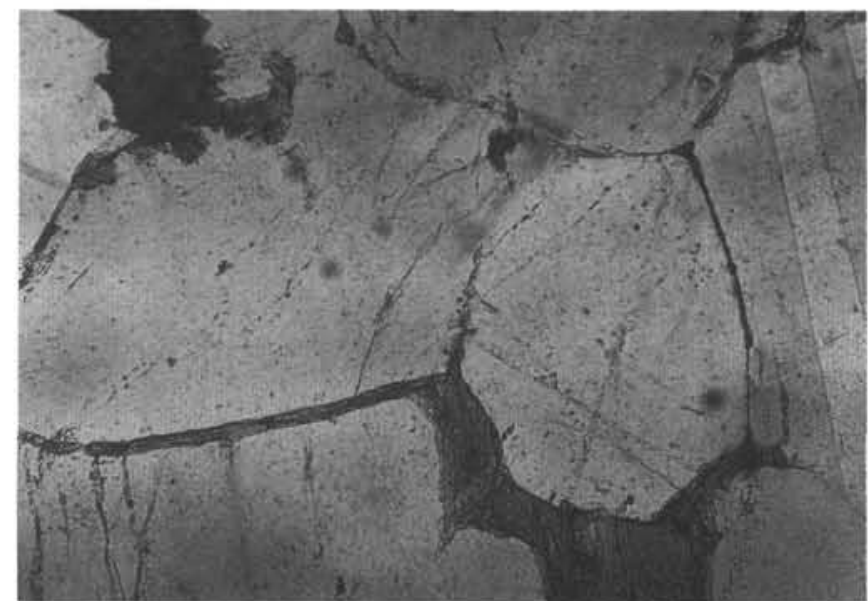

1

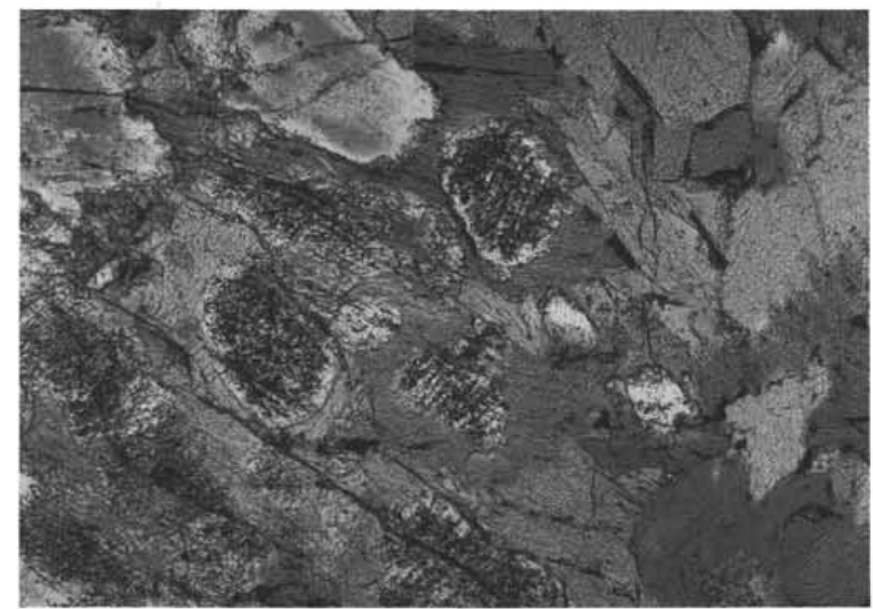

3

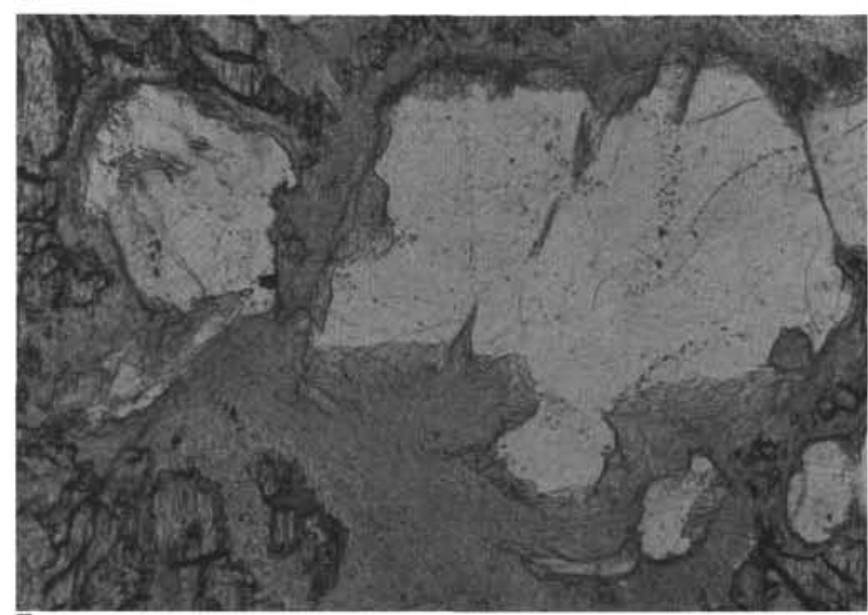

5

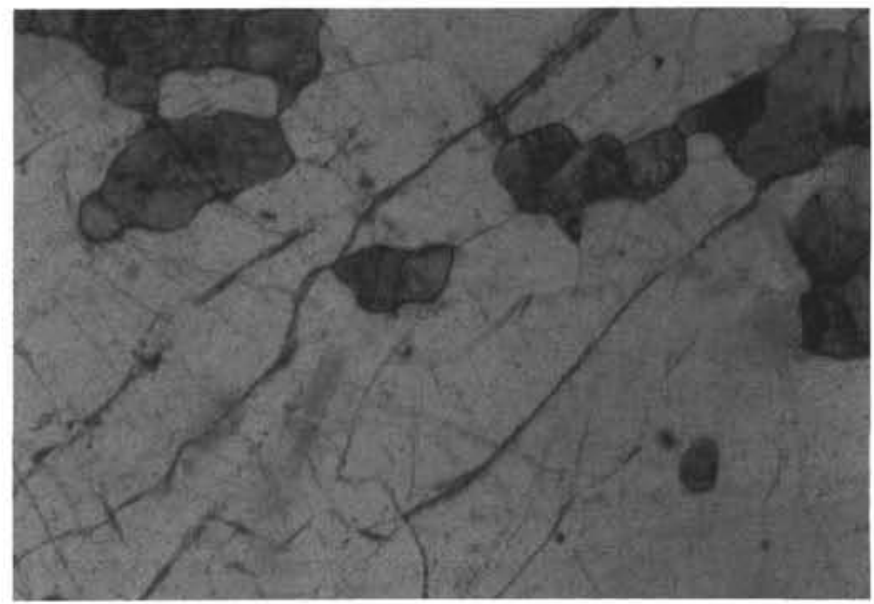

2

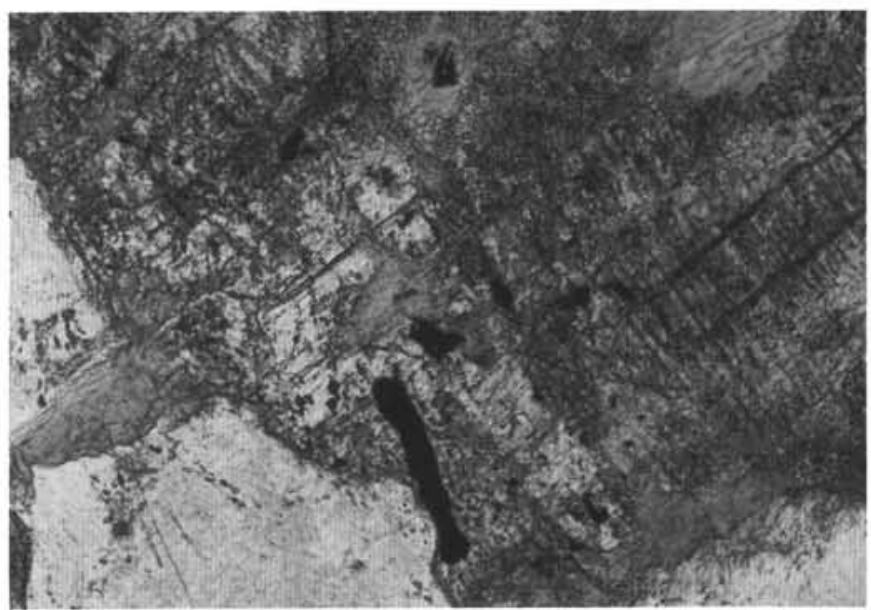

4

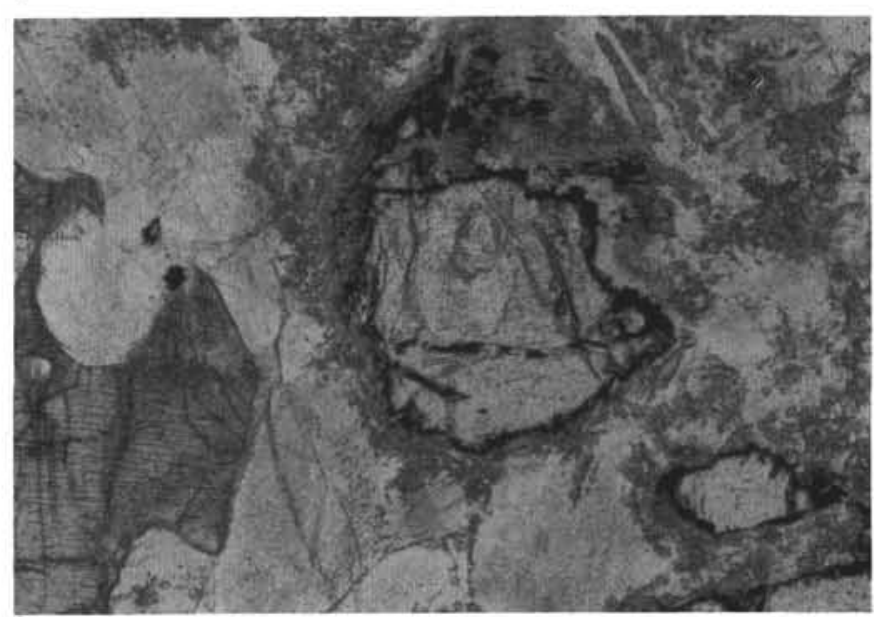

6

Plate 1. Textural characteristics of microscopic amphibole veins and associated alteration. 1. Microscopic amphibole veins at plagioclase-plagioclase grain boundaries. Sample 147-894G-4R-2,33-37 cm; partly crossed polars; field of view is $1 \mathrm{~mm}$ across. 2. Microscopic amphibole veins crosscutting magmatic plagioclase crystals. Sample 147-894G-9R-1, Piece 13, 86-89 cm; plane polarized light; field of view is $2 \mathrm{~mm}$ across. 3. Secondary clinopyroxene rims on altered exsolved magmatic clinopyroxene. Secondary clinopyroxene rims coexist with modally abundant actinolitic hornblende to magnesio-hornblende associated with microscopic amphibole veins. Sample 147-894G-18R-2, Piece 3, 15-17 cm; plane polarized light; field of view is 2 mm across. 4. Secondary clinopyroxene after exsolved magmatic clinopyroxene. Sample 147-894G-17R-2, Piece 5, 44-47 cm; plane polarized light; field of view is $1 \mathrm{~mm}$ across. 5. Actinolite after poikilitic magmatic orthopyroxene. Sample 147-894G-9R-1, Piece 13,86-89 cm; plane polarized light; field of view is 1 mm across. 6. Magnetite, talc, and actinolite replacement of granular olivine. Sample 147-894G-17R-2, Piece 5, $44-47 \mathrm{~cm}$; plane polarized light; field of view is $2 \mathrm{~mm}$ across. 


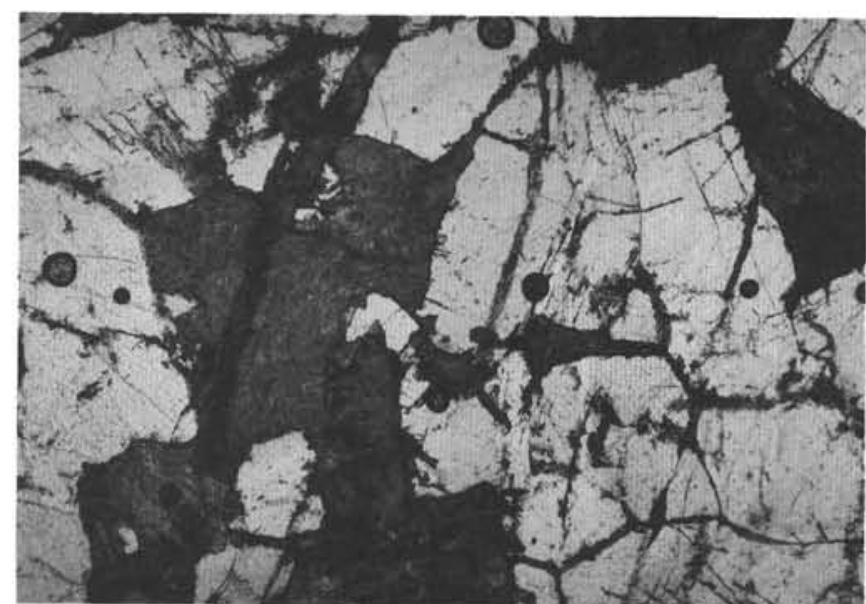

1

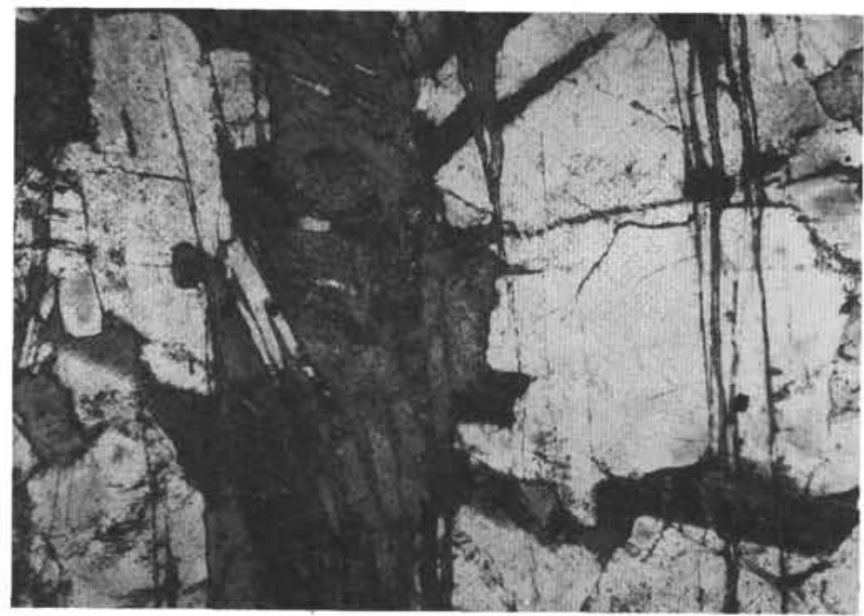

3

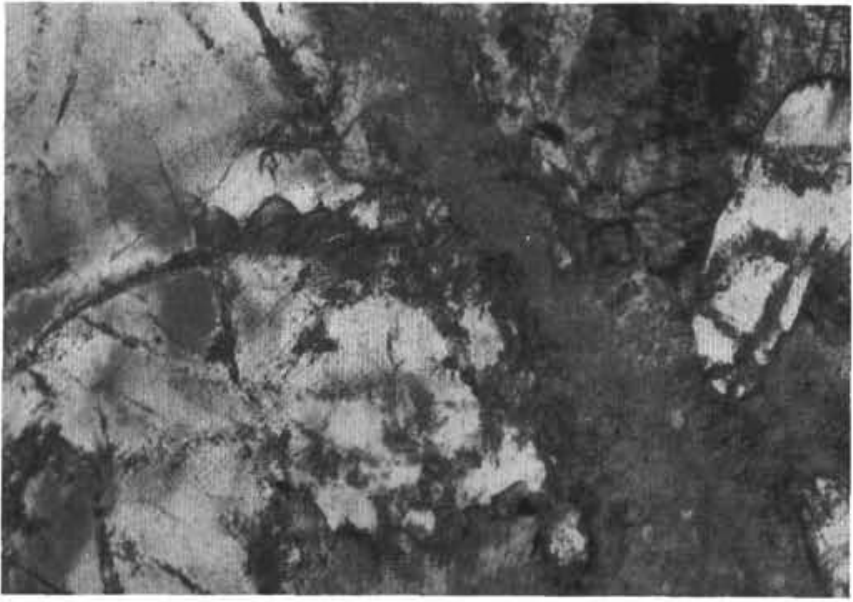

2

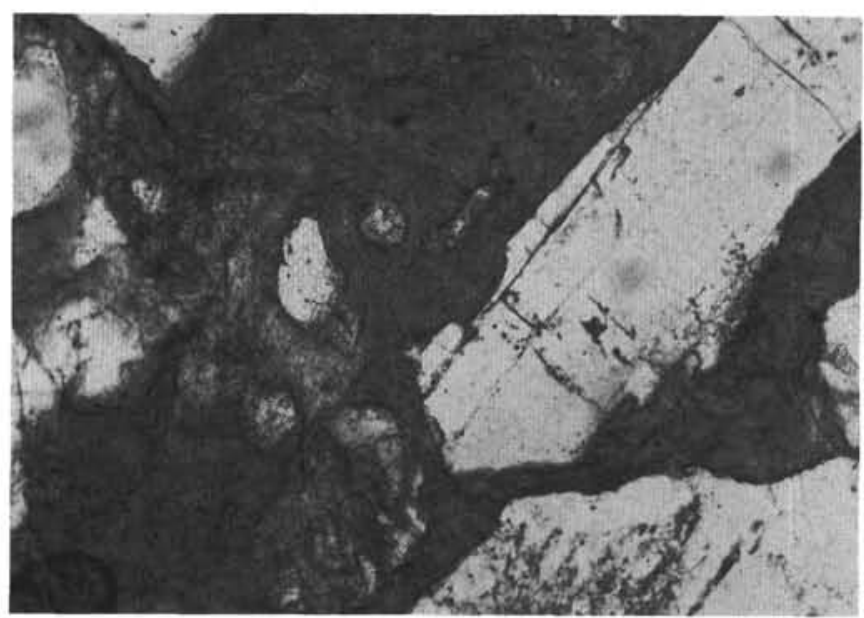

4

Plate 2. Textural characteristics of macroscopic amphibole veins and associated alteration. 1. Macroscopic amphibole vein crosscutting earlier hornblende after magmatic clinopyroxene. Sample 147-894G-4R-2, Piece 7, 33-37 cm; plane polarized light; field of view is $2 \mathrm{~mm}$ across. 2. Macroscopic amphibole vein displaying characteristically wider aperture where clinopyroxene is crosscut and replaced (lower left) relative to plagioclase (center). Sample 147-894G-9R-1, Piece 12, 81-85 cm; plane polarized light; field of view is $2 \mathrm{~mm}$ across. 3. Macroscopic amphibole vein composed of numerous thinner amphibole veins. Sample 147-894G-12R-4, Piece 4A, 30-34 cm; plane polarized light; field of view is $2 \mathrm{~mm}$ across. 4. Altered plagioclase clasts in macroscopic amphibole veins (center) and secondary, inclusion-rich plagioclase after magmatic plagioclase at vein margin (lower left). Sample 147-894G-4R-2, Piece 7, 33-37 cm; plane polarized light; field of view is $2 \mathrm{~mm}$ across. 


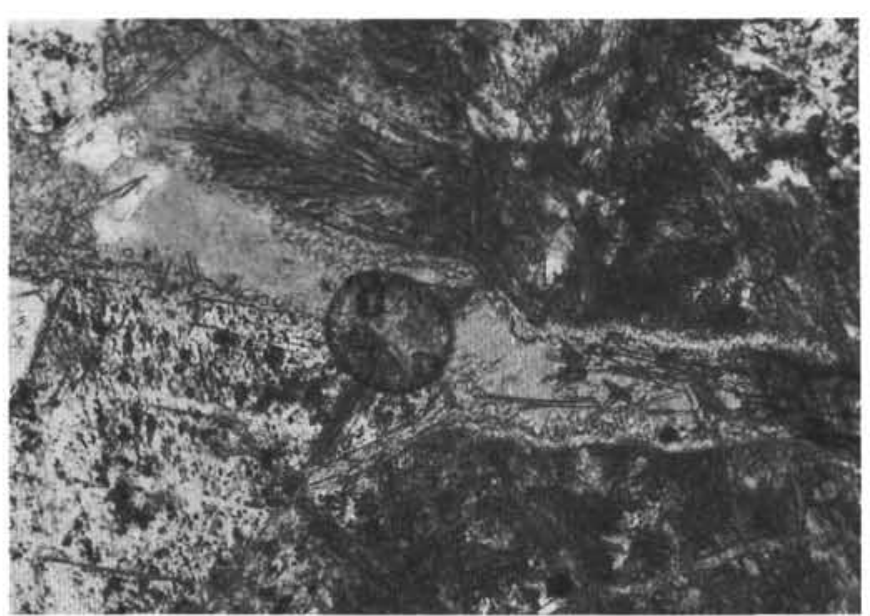

1

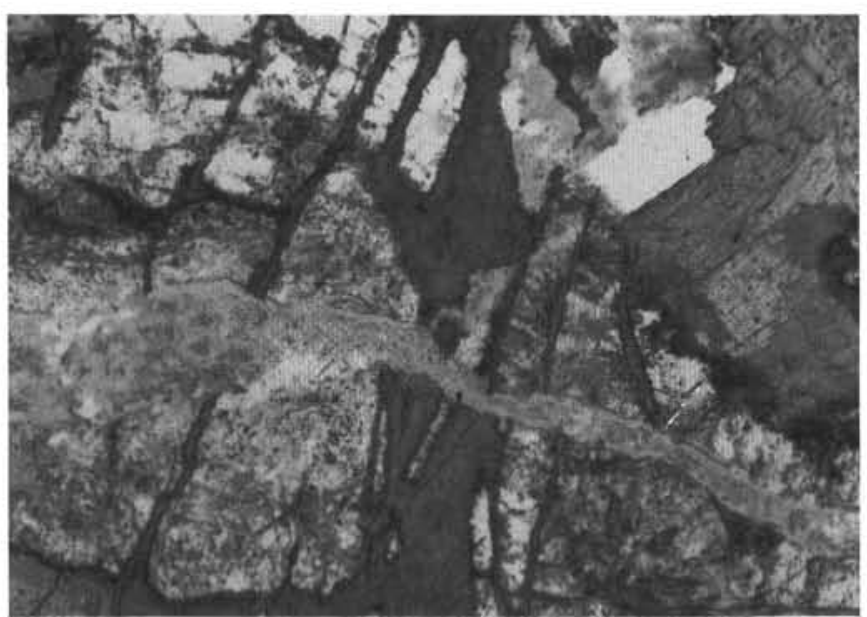

3

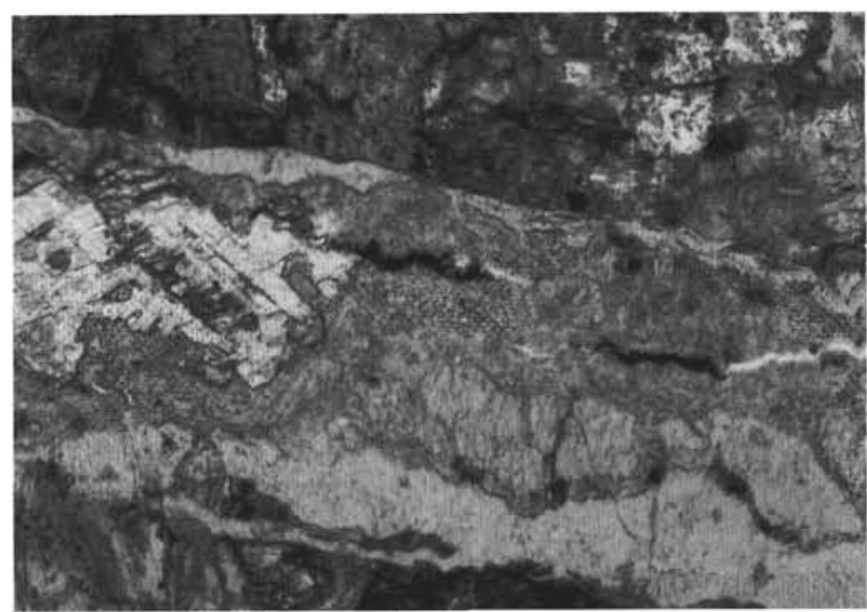

2

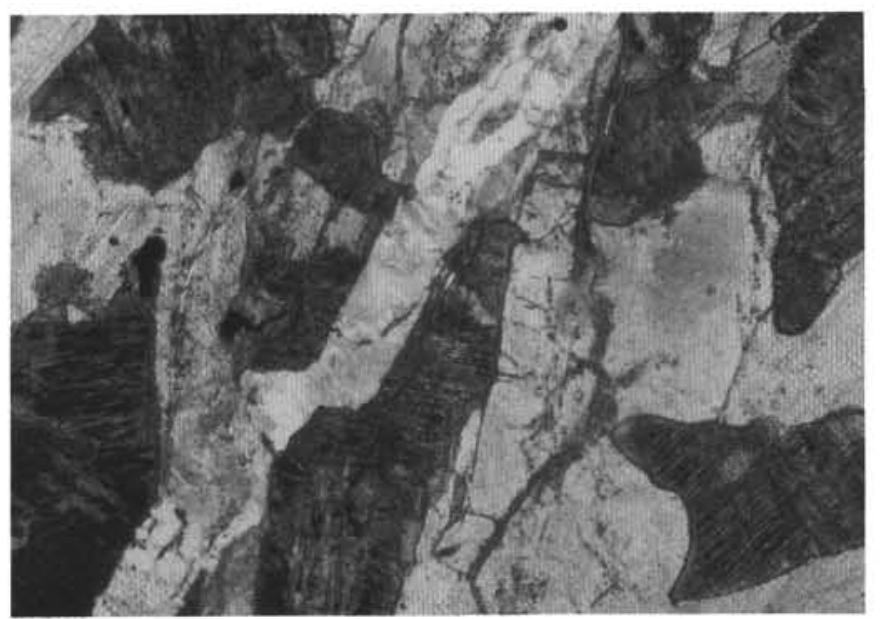

4

Plate 3. Textural characteristics of chlorite-bearing veins and associated alteration. 1. Chlorite-calc-silicate vein displaying characteristic zoning from chlorite vein margin to $\mathrm{Ca}-\mathrm{Al}$ silicate, in this case epidote, vein center. Note strong alteration of wall-rock plagioclase to secondary plagioclase (albite). Sample 147 894G-1 1R-1, Piece 17B, 125-129 cm; plane polarized light; field of view is $1 \mathrm{~mm}$ across. 2. Chlorite-smectite vein displaying characteristic zoning from chlorite vein margin to smectite vein center. Translucent calcite fills residual porosity in vein center. Sample 147-894G-6R-1, Piece 4A, 19-22 cm; plane polarized light; field of view is $2 \mathrm{~mm}$ across. 3. Chlorite-smectite vein crosscutting macroscopic amphibole vein. Note strong alteration of wall-rock plagioclase to inclusion-rich secondary plagioclase (albite). Sample 147-894G-6R-1, Piece 5B, 57-63 cm; plane polarized light; field of view is $2 \mathrm{~mm}$ across. 4. Chlorite-smectite vein crosscutting alteration associated with microscopic amphibole veins. Strong alteration to chlorite and smectite make magmatic clinopyroxene grains nearly opaque. Sample 147-894G-12R-3, Piece 2, 56-59 cm; plane polarized light; field of view is $2 \mathrm{~mm}$ across. 